\title{
Tetrahedron
}

\section{Helical structures of L-Leu-based peptides having chiral six-membered ring amino acids}

\author{
Tomohiro Umeno ${ }^{\mathrm{a}}$, Atsushi Ueda ${ }^{\mathrm{a}}$, Makoto Oba $^{\mathrm{a}}$, Mitsunobu Doi ${ }^{\mathrm{b}}$, Takayuki Hirata ${ }^{\mathrm{c}}$, Hiroshi Suemune $^{\mathrm{c}}$, \\ and Masakazu Tanaka ${ }^{\mathrm{a}} *$ \\ Graduate School of Biomedical Sciences, Nagasaki University, 1-14 Bunkyo-machi, Nagasaki 852-8521, Japan \\ ${ }^{b}$ Osaka University of Pharmaceutical Sciences, Osaka 569-1094, Japan \\ Graduate School of Pharmaceutical Sciences, Kyushu University, Fukuoka 812-8582, Japan
}

\section{ABSTRACT}

Type your Abstract text here

2009 Elsevier Ltd. All rights reserved.

L-Leu-based peptides having chiral six-membered ring amino acids: Boc- $\{$ L-Leu-L-Leu$\left[(1 R, 3 R)-\right.$ or $\left.\left.(1 S, 3 R)-\mathrm{Ac}_{6} \mathrm{c}^{3 \mathrm{M}}\right]\right\}_{\mathrm{n}}-\mathrm{OMe}[\mathrm{n}=1(\mathbf{2}), 2(\mathbf{4}), 3(\mathbf{5})]$, were synthesized. A conformational analysis using FT-IR absorption and NOESY NMR spectra revealed that these hexa- and nonapeptides having $(1 R, 3 R)-\mathrm{Ac}_{6} \mathrm{c}^{3 \mathrm{M}}$ or $(1 S, 3 R)-\mathrm{Ac}_{6} \mathrm{c}^{3 \mathrm{M}}$ formed helical structures in $\mathrm{CDCl}_{3}$ solution, while that using CD spectra suggested that the nonapeptide $\mathbf{5} \mathbf{b}$ having $(1 S, 3 R)$ $\mathrm{Ac}_{6} \mathrm{c}^{3 \mathrm{M}}$ become more right-handed $(P) \alpha$-helical than the nonapeptide 5a having $(1 R, 3 R)$ $\mathrm{Ac}_{6} \mathrm{c}^{3 \mathrm{M}}$ in TFE solution. An X-ray crystallographic analysis showed that the hexapeptide $4 \mathbf{b}$ having $(1 S, 3 R)-\mathrm{Ac}_{6} \mathrm{c}^{3 \mathrm{M}}$ formed a partially distorted right-handed $(P) 3_{10}-/ \alpha$-helical structure in the crystal state, while the nonapeptides $\mathbf{5 a}$ and $\mathbf{5 b}$ having $(1 R, 3 R)-\mathrm{Ac}_{6} \mathrm{c}^{3 \mathrm{M}}$ or $(1 S, 3 R)-\mathrm{Ac}_{6} \mathrm{c}^{3 \mathrm{M}}$ formed similar right-handed $(P) \alpha$-helical backbone structures.

\section{Introduction}

Cyclic $\alpha, \alpha$-disubstituted $\alpha$-amino acids (cyclic dAAs) are $\alpha$ amino acids in which the $\alpha$-hydrogen atom of normal $\alpha$-amino acids is replaced with alkyl substituents and the resultant two side chains become cyclic ring structures. ${ }^{1,2}$ Cyclic dAAs restrict the conformational freedom of their homo- and heteropeptides. Achiral cyclic dAA $\left(\mathrm{Ac}_{\mathrm{n}} \mathrm{c} ; \mathrm{n}=\right.$ ring size $)$-containing oligopeptides have been reported to induce $3_{10} / \alpha$-helical secondary structures. ${ }^{3}$ Toniolo, Balaram, Benedetti, and coworkers studied the preferred structures of 1aminocyclohexanecarboxylic acid $\left(\mathrm{Ac}_{6} \mathrm{c}\right)$-containing peptides. ${ }^{4,5}$ They reported that $\mathrm{Ac}_{6} \mathrm{c}$ homopeptides formed $3_{10}$-helical structures (tripeptide: type III $\beta$-turn, tetrapeptides: $3_{10}$-helices) in the crystal state, and $A_{6} c$ had a chair form cyclohexane conformation. In the chair form of the cyclohexane, the amino (amide) - $\mathrm{NH}-$ substituent showed an axial orientation and the carbonyl - $\mathrm{CO}$ - substituent occupied an equatorial orientation. This orientation was theoretically more stable than the opposite orientation by $\sim 1.6 \mathrm{kcal} / \mathrm{mol}^{6}$. Furthermore, the calculation of Ac-Ac ${ }_{6} \mathrm{c}-\mathrm{NHMe}$ suggested that the lowest energy conformation was torsion angles $\phi \pm 52^{\circ} ; \psi \pm 46^{\circ}$ in the case of the $-\mathrm{NH}-$ axial position, while that with torsion angles $\phi \pm 48^{\circ} ; \psi \pm 60^{\circ 4 \mathrm{~b}}$ (or $\phi$ $\pm 40^{\circ} ; \psi \pm 80^{\circ 4 \mathrm{c}}$ ) was favorable in the case of the $-\mathrm{NH}$ - equatorial position.
We recently reported that the axial and equatorial orientations of amino and carbonyl substituents may be controlled using chiral $(1 R, 3 R)$ - and $(1 S, 3 R)$-1-amino-3methylcyclohexanecarboxylic acids $\left(\mathrm{Ac}_{6} \mathrm{c}^{3 \mathrm{M}}\right){ }^{7}$ Furthermore, we studied the preferred torsion angles of $(1 R, 3 R)$ - and $(1 S, 3 R)$ $\mathrm{Ac}_{6} \mathrm{c}^{3 \mathrm{M}}$ homo-chiral homopeptides. The absolute average values of the $\phi$ and $\psi$ torsion angles of $(1 R, 3 R)$-hexapeptide were $59.0^{\circ}$ and $31.1^{\circ}$, respectively, which were close to the ideal torsion angles $\left(60^{\circ}\right.$ and $\left.30^{\circ}\right)$ of the $30^{\text {-helical structure, }}{ }^{8 \mathrm{a}}$ with the 3 methyl substituent and the - $\mathrm{CO}-$ group at an equatorial position and the $-\mathrm{NH}-$ group at an axial position. On the other hand, those of $(1 S, 3 R)-\mathrm{Ac}_{6} \mathrm{c}^{3 \mathrm{M}}$ hexapeptide were $55.9^{\circ}$ and $47.1^{\circ}$, respectively, which were close to the standard $\alpha$-helix $\left(57^{\circ}\right.$ and $\left.47^{\circ}\right),{ }^{8}$ with the 3-methyl substituent and the -NH- group at an equatorial position and the - $\mathrm{CO}-$ group in an axial direction. Thus, the orientation of the amino (amide) - NH- substituent of the chair form of the cyclohexane affected the secondary structure of its homo-chiral homopeptides (Fig. 1). We herein examined the effects of $(1 R, 3 R)$ - and $(1 S, 3 R)-\mathrm{Ac}_{6} \mathrm{c}^{3 \mathrm{M}}$ on their LLeu-based heteropeptide conformations ${ }^{9}$ in solution and in the crystal state. 


$$
\begin{gathered}
\text { axial } \\
(-\mathrm{NH}-) \mathrm{NH}_{2} \\
\Downarrow \text { hexapeptide } \\
\mathbf{3}_{10^{-}} \text {helix } \\
\phi=59.0^{\circ} ; \psi=31.1^{\circ}
\end{gathered}
$$

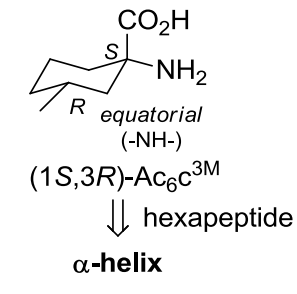

Fig. 1. Structures of chiral six-membered ring $\alpha, \alpha$-disubstituted $\alpha$-amino acids $\mathrm{Ac}_{6} \mathrm{c}^{3 \mathrm{M}}$ and their homopeptide secondary structures. ${ }^{7}$

\section{Results and Discussion}

2.1. Preparation of $(1 R, 3 R)$ - and $(1 S, 3 R)-\mathrm{Ac}_{6} \mathrm{c}^{3 \mathrm{M}}$-containing $\mathrm{L}$ Leu-based heteropeptides

We prepared Boc-\{L-Leu-L-Leu-[(1R,3R)-Ac $\left.\left.{ }_{6}{ }^{3 \mathrm{M}}\right]\right\}_{\mathrm{n}}-\mathrm{OMe}(\mathbf{a})$ and Boc- $\left\{\mathrm{L}-\mathrm{Leu}-\mathrm{L}-\mathrm{Leu}-\left[(1 S, 3 R)-\mathrm{Ac}_{6} \mathrm{c}^{3 \mathrm{M}}\right]\right\}_{\mathrm{n}} \mathrm{OMe}(\mathbf{b})(\mathrm{n}=1,2,3)$ using solution-phase methods. Tripeptide Boc-\{L-Leu-L-Leu$\left.\left[(1 R, 3 R)-\mathrm{Ac}_{6} \mathrm{c}^{3 \mathrm{M}}\right]\right\}-\mathrm{OMe}(\mathbf{2 a})$ was prepared by coupling between Boc-(L-Leu-L-Leu)- $\mathrm{OH}^{9}$ and $(1 R, 3 R)-\mathrm{Ac}_{6} \mathrm{c}^{3 \mathrm{M}}$-OMe (1a) $)^{7}$ using 1 ethyl-3-(3-dimethylaminopropyl)carbodiimide hydrochloride (EDCI) and 1-hydroxybenzotriazole (HOBt) as coupling reagents in $86 \%$ yield. The hydrolysis of the ester in $\mathbf{2 a}$ under alkaline conditions $\left(\mathrm{NaOH} / \mathrm{H}_{2} \mathrm{O}-\mathrm{MeOH}\right)$ gave a tripeptide acid (3a) in a quantitative yield, while the deprotection of the Boc-protecting group in 2a under acidic conditions afforded a tripeptide amine in 94\% yield. Coupling between the tripeptide acid (3a) and tripeptide amine using EDCI and HOBt gave a hexapeptide Boc$\left\{\mathrm{L}-\text { Leu-L-Leu- }\left[(1 R, 3 R)-\mathrm{Ac}_{6} \mathrm{c}^{3 \mathrm{M}}\right]\right\}_{2}-\mathrm{OMe} \quad(\mathbf{4 a})$ in $85 \%$ yield. Similarly, coupling between the tripeptide acid (3a) and hexapeptide amine gave a nonapeptide Boc-\{L-Leu-L-Leu$\left.\left[(1 R, 3 R)-\mathrm{Ac}_{6} \mathrm{c}^{3 \mathrm{M}}\right]\right\}_{3}-\mathrm{OMe}(\mathbf{5 a})$ in $76 \%$ yield. No epimerization of peptides was observed in Boc deprotection and fragment condensation, which was confirmed by ${ }^{1} \mathrm{H}$ NMR spectrum measurements. ${ }^{10}$

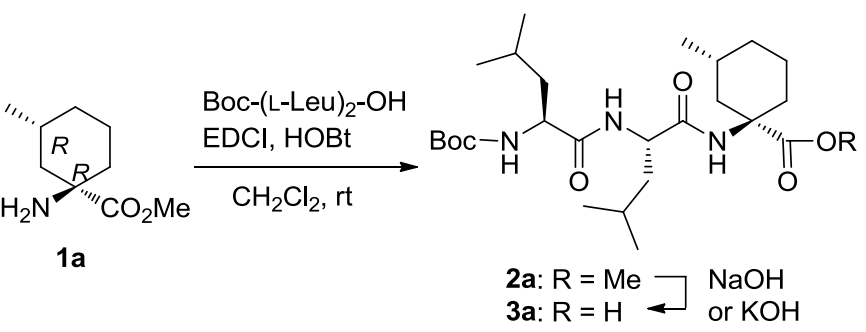

4a: $n=2 ; 5 a: n=3$

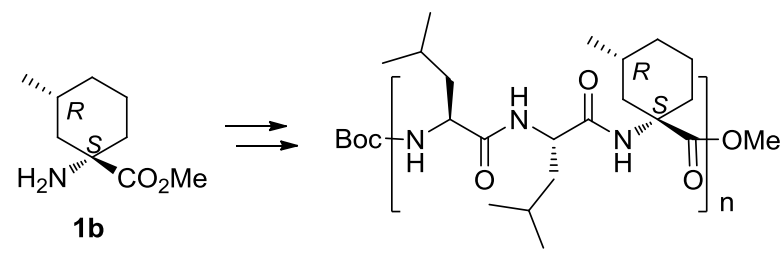

2b: $n=1 ; \mathbf{4 b}: n=2 ; \mathbf{5 b}: n=3$

Scheme 1. Preparation of peptides Boc- $\{$ L-Leu-L-Leu-[(1R,3R)- \& $(1 S, 3 R)$ $\left.\left.\mathrm{Ac}_{6} \mathrm{c}^{3 \mathrm{M}}\right]\right\}_{\mathrm{n}}-\mathrm{OMe}\{\mathrm{n}=1(\mathbf{2}), 2(4), 3(\mathbf{5})\}$.

The $(1 S, 3 R)-\mathrm{Ac}_{6} \mathrm{c}^{3 \mathrm{M}}$-containing heteropeptides Boc- $\{\mathrm{L}-\mathrm{Leu}-\mathrm{L}-$ Leu- $\left.\left[(1 S, 3 R)-\mathrm{Ac}_{6} \mathrm{c}^{3 \mathrm{M}}\right]\right\}_{\mathrm{n}}-\mathrm{OMe}(\mathbf{2 b}, \mathbf{4 b}, \mathbf{5 b})(\mathrm{n}=1,2,3)$ were prepared in a manner similar to those of $(1 R, 3 R)-\mathrm{Ac}_{6} \mathrm{c}^{3 \mathrm{M}}$ heteropeptides, however, the hydrolysis of the C-terminal ester was performed using aqueous $\mathrm{KOH}$ (stronger basicity) in $\mathrm{MeOH}$ (Scheme 1).

\subsection{Conformational analysis in solution}

The dominant conformations of $(1 R, 3 R)-$ and $(1 S, 3 R)-\mathrm{Ac}_{6} \mathrm{c}^{3 \mathrm{M}}$ heteropeptides in solution were examined by using FT-IR absorption, ${ }^{1} \mathrm{H}$ NMR, and $\mathrm{CD}$ spectroscopies at room temperature.

The FT-IR absorption spectra of Boc- $\{$ L-Leu-L-Leu-[( $1 R, 3 R)$ $\left.\left.\mathrm{Ac}_{6} \mathrm{c}^{3 \mathrm{M}}\right]\right\}_{n}$-OMe $[n=1(\mathbf{2 a}), 2(\mathbf{4 a}), 3(\mathbf{5 a})]$ and Boc- $\{$ L-Leu-LLeu- $\left.\left[(1 S, 3 R)-\mathrm{Ac}_{6} \mathrm{c}^{3 \mathrm{M}}\right]\right\}_{n}$-OMe $[n=1(\mathbf{2 b}), 2(\mathbf{4 b}), 3(\mathbf{5 b})]$ in the $3500-3200 \mathrm{~cm}^{-1}$ region at a peptide concentration of $5.0 \mathrm{mM}$ in $\mathrm{CDCl}_{3}$ solution are shown in Figure 2. The FT-IR absorption spectra of helical peptides generally showed free (solvated) peptide NH groups at the $3420-3450 \mathrm{~cm}^{-1}$ region, and peptide $\mathrm{NH}$ groups with $\mathrm{N}-\mathrm{H} \cdots \mathrm{O}=\mathrm{C}$ intramolecular hydrogen bonds of different strengths at the $3320-3370 \mathrm{~cm}^{-1}$ region. $^{9}$ The tripeptides $\mathbf{2 a}$ and $\mathbf{2 b}$ both showed a band at the $3440-3445 \mathrm{~cm}^{-1}$ region, but no band at the $3320-3370 \mathrm{~cm}^{-1}$ region. These results may be attributed to the tripeptide being too short for the helical structure, and the $\beta$-turn structure being relatively flexible. Also, the proteinogenic dipeptide sequence -L-Leu-L-Leu- is not expected to fold. ${ }^{11}$ The FT-IR absorption spectra of the hexapeptides $\mathbf{4 a}$ and $\mathbf{4 b}$ and nonapeptides $\mathbf{5 a}$ and $\mathbf{5 b}$ showed weak bands at the $3430-3440 \mathrm{~cm}^{-1}$ region, as well as strong bands at the $3330-3340 \mathrm{~cm}^{-1}$ region. These FT-IR absorption spectra were similar to those of helical peptides. ${ }^{9}$

a)

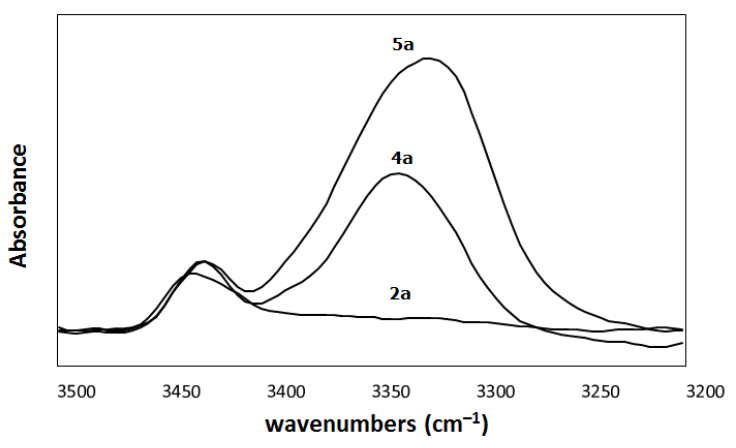

b)

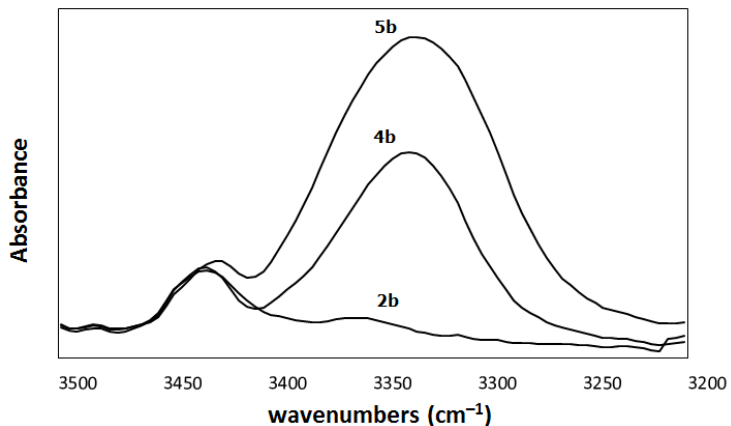


Fig. 2. FT-IR absorption spectra of a) Boc-\{L-Leu-L-Leu-[(1R,3R)$\left.\left.\mathrm{Ac}_{6} \mathrm{c}^{3 \mathrm{M}}\right]\right\}_{n}$-OMe $[n=1$ (2a), 2 (4a), 3 (5a)] and b) Boc- $\{$ L-Leu-L-Leu$\left.\left[(1 S, 3 R)-\mathrm{Ac}_{6} \mathrm{c}^{3 \mathrm{M}}\right]\right\}_{n}$-OMe $[n=1(\mathbf{2 b}), 2(\mathbf{4 b}), 3(\mathbf{5 b})]$.

1

2
The 2D nuclear Overhauser and exchange spectroscopies (NOESY) NMR of the nonapeptides $\mathbf{5} \mathbf{a}$ and $\mathbf{5 b}$ were measured in $\mathrm{CDCl}_{3}$ solution (Fig. 3).

The NOESY NMR spectrum of the $(1 R, 3 R)-\mathrm{Ac}_{6} \mathrm{c}^{3 \mathrm{M}}$ nonapeptide 5a showed a series of sequential $\mathrm{NH}(i \rightarrow i+1)$ dipolar interactions from the $\mathrm{N}$-terminal $\mathrm{N}(1) \mathrm{H}$ to the $\mathrm{C}$-terminal $\mathrm{N}(9) \mathrm{H}$, except for the NOE constrain $\mathrm{NH}(2 \rightarrow 3)$ (Fig. 3a). On the other hand, the $(1 S, 3 R)-\mathrm{Ac}_{6} \mathrm{c}^{3 \mathrm{M}}$ nonapeptide $\mathbf{5 b}$ showed a series of sequential $\mathrm{NH}(i \rightarrow i+1)$ dipolar interactions from the $\mathrm{N}$-terminal $\mathrm{N}(1) \mathrm{H}$ to the $\mathrm{C}$-terminal $\mathrm{N}(9) \mathrm{H}$, except for the $\mathrm{NOE}$ constrain NH $(5 \rightarrow 6)$ (Fig. 3b). These sequential NOE constraints suggested helical conformations. However, we were unable to determine whether a $3_{10^{-}}$or $\alpha$-helical conformation was present because an overlap of $\alpha$-proton signals occurred, and, thus, it was not possible to analyze the NOE constraints $\left[d_{\alpha \mathrm{N}}(i \rightarrow\right.$ $i+2)]$ and $\left[d_{\alpha \mathrm{N}}(i \rightarrow i+4)\right] .^{12}$
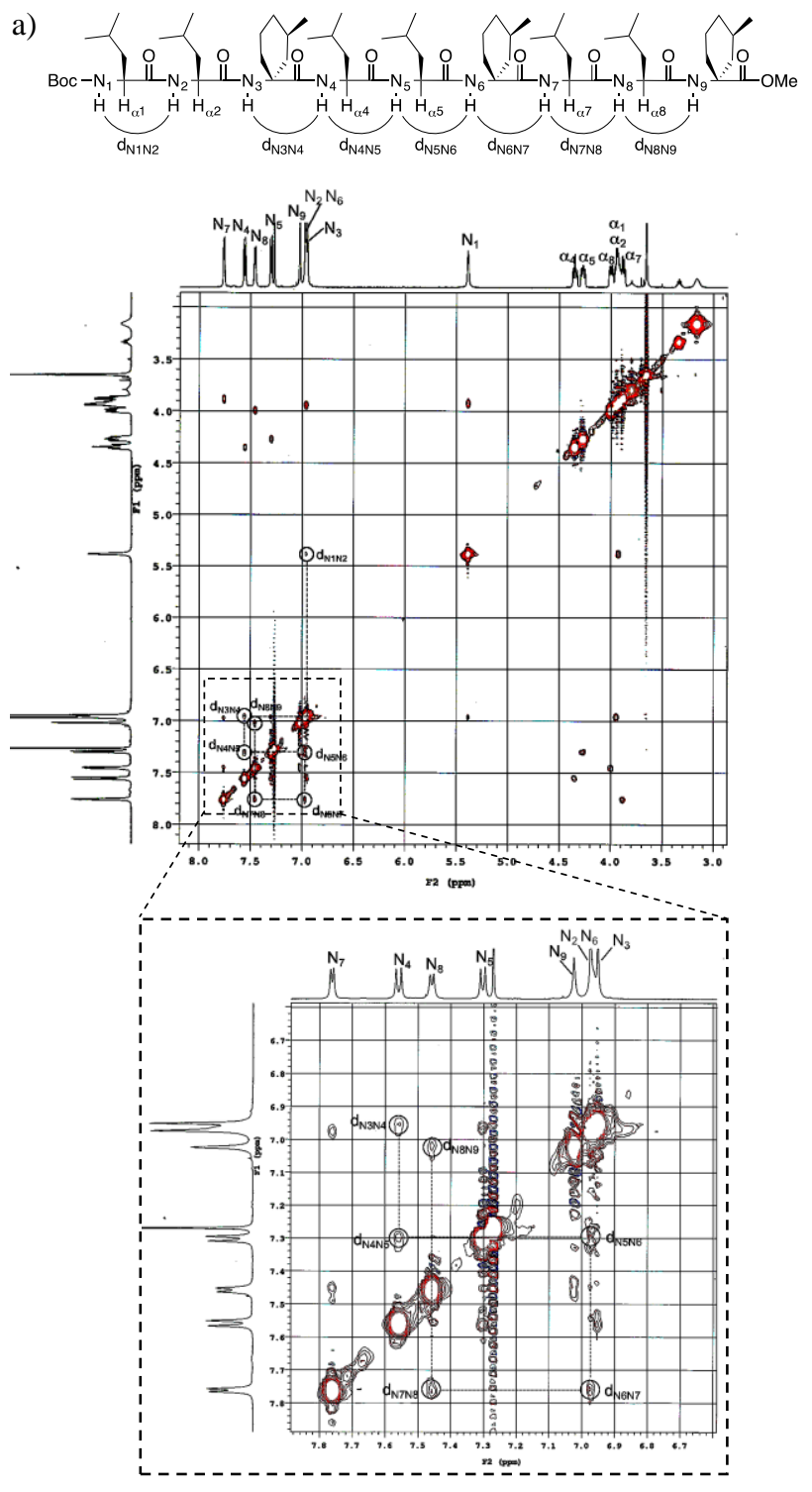
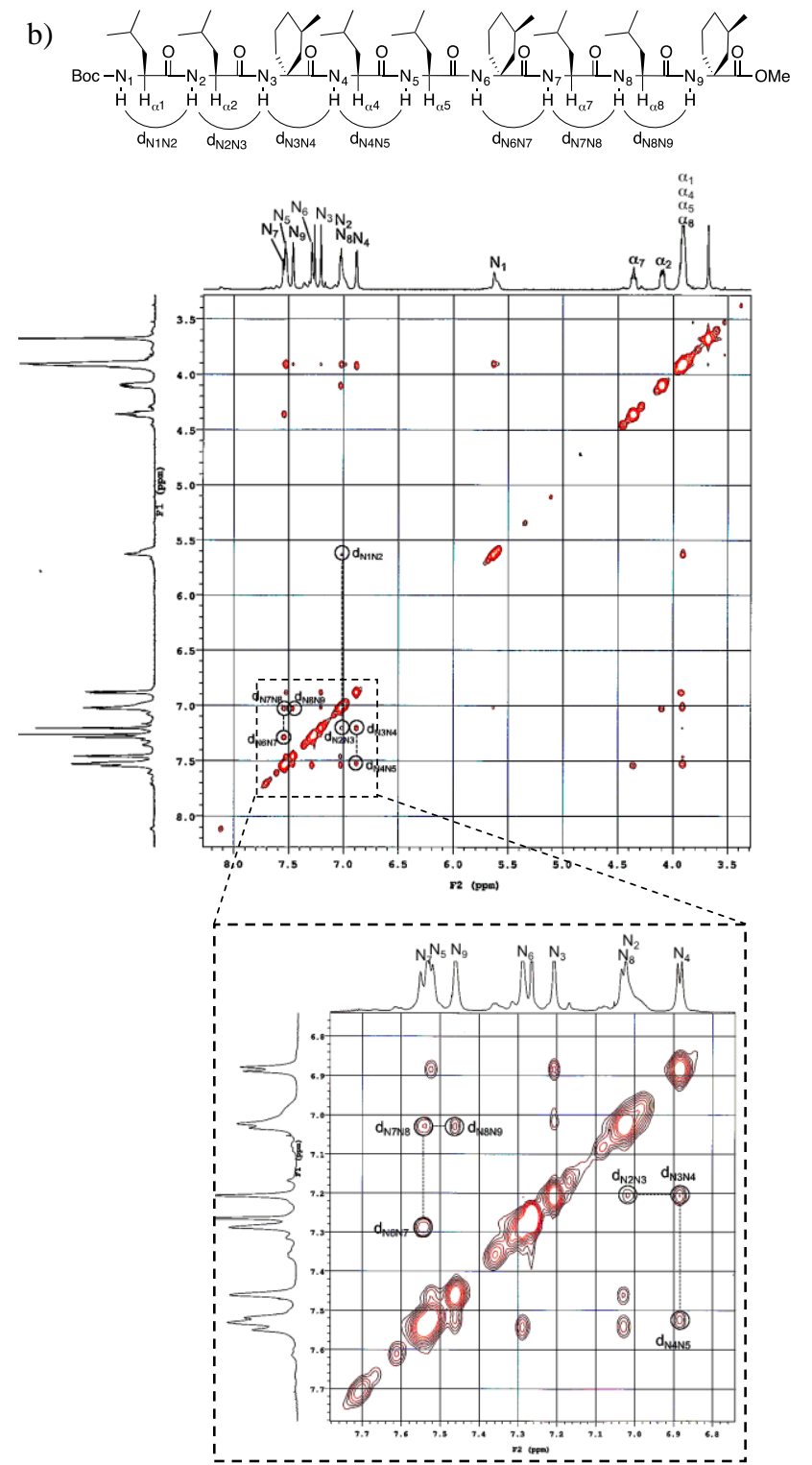

Fig. 3. NOESY NMR spectra of nonapeptides. a) Boc-\{L-Leu-L-Leu$\left.\left[(1 R, 3 R)-\mathrm{Ac}_{6} \mathrm{c}^{3 \mathrm{M}}\right]\right\}_{3}-\mathrm{OMe}(\mathbf{5 a})$, and b) Boc-\{L-Leu-L-Leu- $\left.\left[(1 S, 3 R)-\mathrm{Ac}_{6} \mathrm{c}^{3 \mathrm{M}}\right]\right\}_{3^{-}}$ OMe (5b).

Figure 4 shows the CD spectra of the hexapeptides $\mathbf{4 a}$ and $\mathbf{4 b}$ and nonapeptides $\mathbf{5 a}$ and $\mathbf{5 b}$ in 2,2,2-trifluoroethanol (TFE) solution. The characteristics of the right-handed $(P)$ helical peptide in CD spectra showed a positive maximum at $192 \mathrm{~nm}$, and negative maxima at $208 \mathrm{~nm}$ and $222 \mathrm{~nm} .{ }^{13}$ The $(1 R, 3 R)$ $\mathrm{Ac}_{6} \mathrm{c}^{3 \mathrm{M}}$ and $(1 S, 3 R)-\mathrm{Ac}_{6} \mathrm{c}^{3 \mathrm{M}}$ hexapeptides $\mathbf{4 a}$ and $\mathbf{4 b}$ both showed weak negative maxima at $204 \mathrm{~nm}$ (blue shift is seen) and $222 \mathrm{~nm}$; however, the positive maximum at $192 \mathrm{~nm}$ was not clear. These negative maxima suggested the formation of a right-handed $(P)$ helical structure. Right-handedness may be controlled by four LLeu residues, and the weak intensity of maxima may be attributed to the length of the hexapeptide being insufficient to form a one-handed stable helical conformation. The 
nonapeptides $\mathbf{5 a}$ and $\mathbf{5 b}$ showed a positive maximum at $192 \mathrm{~nm}$, and negative maxima at approximately $205-207 \mathrm{~nm}$ and $222 \mathrm{~nm}$, suggesting the formation of right-handed $(P)$ helical 1 conformations. The intensity of molar ellipticity in the $(1 S, 3 R)$ $\mathrm{Ac}_{6} \mathrm{c}^{3 \mathrm{M}}$ nonapeptide $\mathbf{5 b}$ become stronger than that in $\mathbf{5 b}$, 3 suggesting an increase in the helical content of $\mathbf{5 b}$. Based on $R$ values (ratio of maxima), the $(1 R, 3 R)-\mathrm{Ac}_{6} \mathrm{c}^{3 \mathrm{M}}$ nonapeptide $\mathbf{5 a}$ appeared to form a right-handed $3_{10}$-helix $\left(\theta_{222} / \theta_{205} ; 0.48\right)$, while the $(1 S, 3 R)-\mathrm{Ac}_{6} \mathrm{c}^{3 \mathrm{M}}$ nonapeptide $\mathbf{5 b}$ appeared to form a mixture of $3_{10} / \alpha$-helix $\left(\theta_{222} / \theta_{207} ; 0.60\right)$

a)

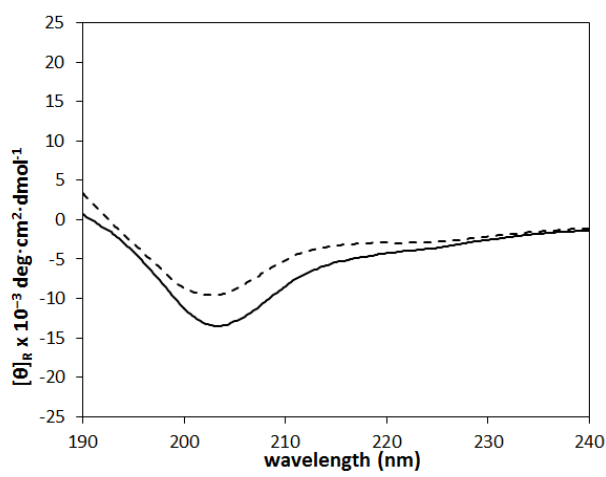

b)

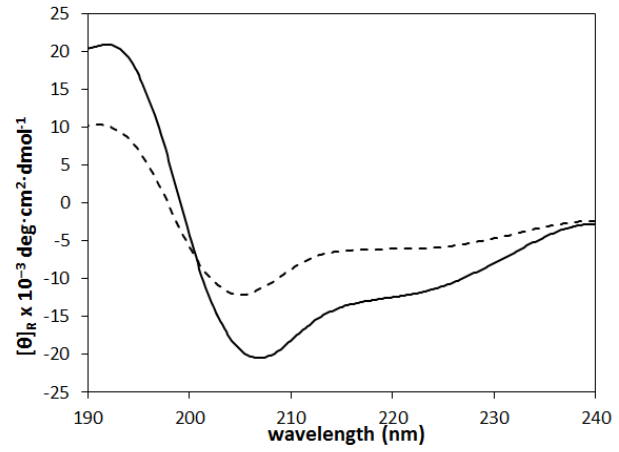

Fig. 4. CD spectra of a) hexapeptides $4 \mathbf{a}$ (dash line) and $\mathbf{4 b}$ (solid line) and b) nonapeptides 5a (dash line) and $\mathbf{5 b}$ (solid line) in TFE solution. Concentration: $0.05 \mathrm{mM}$.

2.3. Crystal structures of $(1 R, 3 R)-$ and $(1 S, 3 R)-\mathrm{Ac}_{6} \mathrm{c}^{3 \mathrm{M}}$ containing $L-L e u-b a s e d$ heteropeptides in the crystal state

The crystal and diffraction parameters of the $(1 R, 3 R)-\mathrm{Ac}_{6} \mathrm{c}^{3 \mathrm{M}}$ and $(1 S, 3 R)$-peptides $\mathbf{4 b}, \mathbf{5 a}$, and $\mathbf{5 b}$ are summarized in Table $1 .{ }^{14,15}$ No suitable crystals of $\mathbf{4 a}$ were obtained for X-ray crystallographic analysis. Their molecular structures are given in Figures 5-8. Relevant backbone and side-chain torsion angles as well as intra- and intermolecular hydrogen-bond parameters are listed in Tables 2 and 3.

The structure of the $(1 S, 3 R)-\mathrm{Ac}_{6} \mathrm{c}^{3 \mathrm{M}}$ hexapeptide $\mathbf{4 b}$ was solved in the space group $P 2{ }_{1} 2_{l} 2_{l}$. A right-handed $(P)$ helical structure, along with one water molecule, existed in the asymmetric unit. The N-terminal Boc-protecting group was disordered. Figure 5 shows a right-handed $(P) 3_{10} / \alpha$-helical structure, in which the $\phi$ and $\psi$ torsion angles of the penultimate L-Leu (5) residue were distorted. The average $\phi$ and $\psi$ torsion angles of residues (2-4 and 6) were $-57.0^{\circ}$ and $-40.2^{\circ}$, respectively, were intermediate values between the ideal righthanded $(P) 310^{-h e l i c a l}$ structure $\left(-60^{\circ}\right.$ and $\left.-30^{\circ}\right)$ and $(P) \alpha$-helix $\left(-57^{\circ}\right.$ and $\left.-47^{\circ}\right){ }^{8}$ The conformation of side-chain cyclohexane rings at residues (3) and (6) were in the chair form, with the 3- methyl substituent and $-\mathrm{NH}-$ group at an equatorial orientation and the $-\mathrm{CO}$ - group in an axial direction. Corresponding torsion angles $(\chi, \chi$ ') relating the cyclohexyl ring to the peptide chain showed nearly $-180^{\circ}$ and $+180^{\circ}$, which indicated that the $-\mathrm{NH}-$ groups occupied the equatorial positions (Table 2). ${ }^{4 \mathrm{c}}$

Two intramolecular hydrogen bonds of the $i \leftarrow i+3$ type $\left(3_{10^{-}}\right.$ helix) were observed between $\mathrm{H}-\mathrm{N}(4)$ and $\mathrm{C}(1)=\mathrm{O}(1)$ $[\mathrm{N}(4) \cdots \mathrm{O}(1)=2.90 \AA]$ and between $\mathrm{H}-\mathrm{N}(5)$ and $\mathrm{C}(2)=\mathrm{O}(2)$ $[\mathrm{N}(5) \cdots \mathrm{O}(2)=2.92 \AA]$. Furthermore, the intramolecular hydrogen bond of the $i \leftarrow i+3$ type was weak between $\mathrm{H}-\mathrm{N}(6)$ and $\mathrm{C}(3)=\mathrm{O}(3)[\mathrm{N}(6) \cdots \mathrm{O}(3)=3.37 \AA]$. The intramolecular hydrogen bond of the $i \leftarrow i+4$ type ( $\alpha$-helix) was also weak between $\mathrm{H}-\mathrm{N}(5)$ and $\mathrm{C}(1)=\mathrm{O}(1)[\mathrm{N}(5) \cdots \mathrm{O}(1)=3.32 \AA]$. Thus, $\mathrm{H}-\mathrm{N}(5)$ was bound by bifurcated hydrogen bonds to $\mathrm{C}(1)=\mathrm{O}(1)$ and $\mathrm{C}(2)=\mathrm{O}(2)$. The distance between $\mathrm{H}-\mathrm{N}(6)$ and $\mathrm{C}(2)=\mathrm{O}(2)$ was $3.19 \AA$, which was within the hydrogen-bonding distance, whereas the angle for $\mathrm{N}(6)-\mathrm{H} \cdots \mathrm{O}(2)$ was $106^{\circ}$, which was too small for the hydrogen bond. Therefore, the intramolecular hydrogen bond of the $i \leftarrow i+4$ type may not be formed between them. In the packing mode, bifurcated intermolecular hydrogen bonds were observed between $\mathrm{H}-\mathrm{N}(1)$ and $\mathrm{H}-\mathrm{N}(2)$ peptide donors and the $\mathrm{C}\left(4^{\prime}\right)=\mathrm{O}\left(4^{\prime}\right)$ acceptor of a symmetry-related $(1 / 2-\mathrm{x},-\mathrm{y}, 1 / 2+\mathrm{z})$ molecule. Furthermore, the $\mathrm{H}-\mathrm{N}(3)$ peptide donor was hydrogen bonded to the symmetry-related $(-\mathrm{x}, 1 / 2+\mathrm{y}, 1 / 2-\mathrm{z}) \mathrm{O}_{\mathrm{w}}$ of water, and $\mathrm{H}-\mathrm{O}_{\mathrm{w}}$ was hydrogen bonded to the $\mathrm{C}\left(5^{\prime}\right)=\mathrm{O}\left(5^{\prime}\right)$ acceptor.

a)

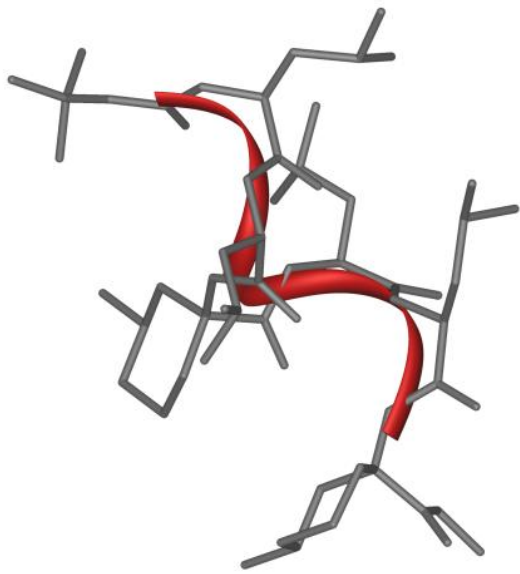

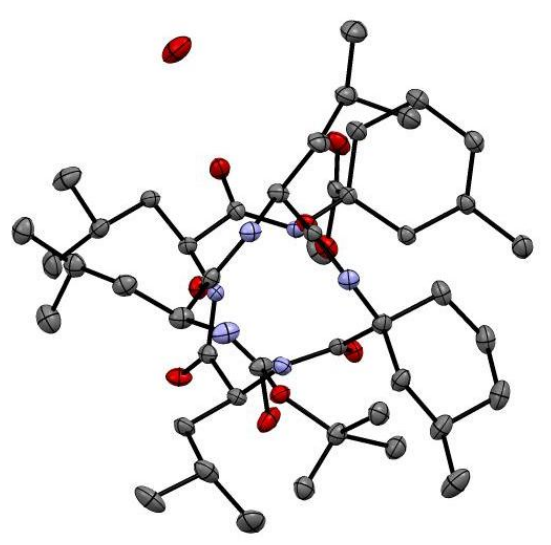

Fig. 5. Right-handed $(P) 3_{10} / \alpha$-helical structure of the $(1 S, 3 R)-\mathrm{Ac}_{6} \mathrm{c}^{3 \mathrm{M}}$ hexapeptide $\mathbf{4 b}$ by an X-ray crystallographic analysis. a) View perpendicular to the helical axis and b) an ORTEP drawing as viewed along the helical axis. 
The $(1 R, 3 R)-\mathrm{Ac}_{6} \mathrm{c}^{3 \mathrm{M}}$ nonapeptide 5a was solved in the space group of $P 2_{1}$ to form a right-handed $(P) \alpha$-helical structure together with three water molecules in the asymmetric unit (Fig.

6). The average $\phi$ and $\psi$ torsion angles of residues (1-7) were $-60.5^{\circ}$ and $-43.6^{\circ}$, respectively, which were consistent with those of the ideal $(P) \alpha$-helix $\left(-57^{\circ}\right.$ and $\left.-47^{\circ}\right) ;^{8}$ however, the $\phi$ and $\psi$ torsion angles of C-terminal $(1 R, 3 R)-\mathrm{Ac}_{6} \mathrm{c}^{3 \mathrm{M}}(9)$ and penultimate L-Leu (8) residues were distorted, and the sign of the $\phi$ torsion angle of residue (9) reverted to positive. Three sidechain cyclohexane rings at residues (3), (6), and (9) formed chairform conformations. The torsion angles $\left(\chi, \chi^{\prime}\right)$ relating the cyclohexyl ring to the peptide chain showed nearly $-60^{\circ}$ and $+60^{\circ}$, which indicated that the $-\mathrm{NH}-$ groups occupied the axial positions. ${ }^{4 c}$ Thus, the 3 -methyl substituent and the $-\mathrm{CO}-$ group of cyclohexane occupied an equatorial orientation, while the $\mathrm{NH}-$ group pointed in an axial direction.

Six intramolecular hydrogen bonds of the $i \leftarrow i+4$ type $(\alpha-$ helix) were observed between $\mathrm{H}-\mathrm{N}(4)$ and the $\mathrm{C}(0)=\mathrm{O}(0)$ oxygen atom of the Boc-group $[\mathrm{N}(4) \cdots \mathrm{O}(0)=3.14 \AA]$, between $\mathrm{H}-\mathrm{N}(5)$ and $\mathrm{C}(1)=\mathrm{O}(1)[\mathrm{N}(5) \cdots \mathrm{O}(1)=2.93 \AA]$, between $\mathrm{H}-\mathrm{N}(6)$ and $\mathrm{C}(2)=\mathrm{O}(2) \quad[\mathrm{N}(6) \cdots \mathrm{O}(2)=3.07 \AA]$, between $\mathrm{H}-\mathrm{N}(7)$ and $\mathrm{C}(3)=\mathrm{O}(3) \quad[\mathrm{N}(7) \cdots \mathrm{O}(3)=3.19 \AA]$, between $\mathrm{H}-\mathrm{N}(8)$ and $\mathrm{C}(4)=\mathrm{O}(4)[\mathrm{N}(8) \cdots \mathrm{O}(4)=2.88 \AA]$, and between $\mathrm{H}-\mathrm{N}(9)$ and $\mathrm{C}(5)=\mathrm{O}(5)[\mathrm{N}(9) \cdots \mathrm{O}(5)=3.00 \AA]$. In the packing mode, an intermolecular hydrogen bond was observed between the $\mathrm{H}-\mathrm{N}(1)$ peptide donor and $\mathrm{C}\left(8^{\prime}\right)=\mathrm{O}\left(8^{\prime}\right)$ of a symmetry-related $(1-\mathrm{x}$, $-1 / 2+y,-z)$ molecule. Furthermore, the peptide $\mathrm{H}-\mathrm{N}(2)$ donor was intermolecularly hydrogen-bonded to a water $\mathrm{O}_{w 3}$, and three water molecules formed a cluster. The water $\mathrm{H}-\mathrm{O}_{\mathrm{w} 1}$ donor formed hydrogen bonds with $\mathrm{C}(8)=\mathrm{O}(8)$ and with the $\mathrm{C}(6)=\mathrm{O}(6)$ of the symmetry-related $(-1+\mathrm{x}, \mathrm{y}, \mathrm{z})$ molecule. The water $\mathrm{H}-\mathrm{O}_{\mathrm{w} 2}$ donor formed hydrogen bonds with the $\mathrm{C}(6)=\mathrm{O}(6)$ and $\mathrm{C}(7)=\mathrm{O}(7)$ acceptors of the peptide.

a)

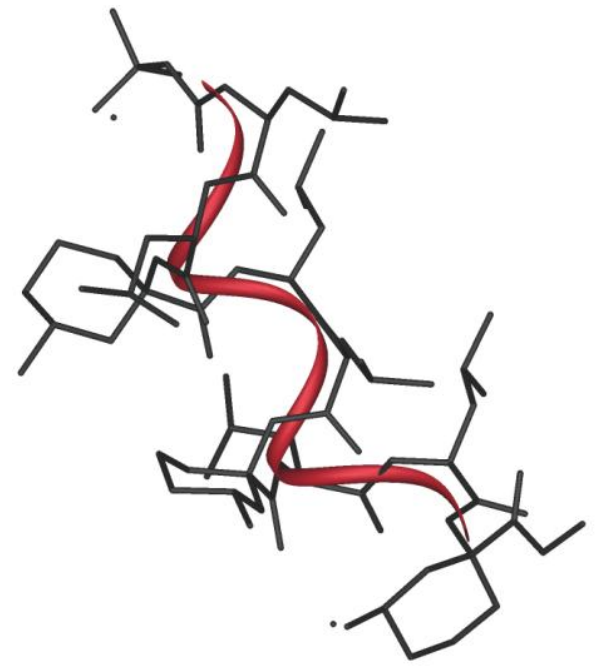

b)

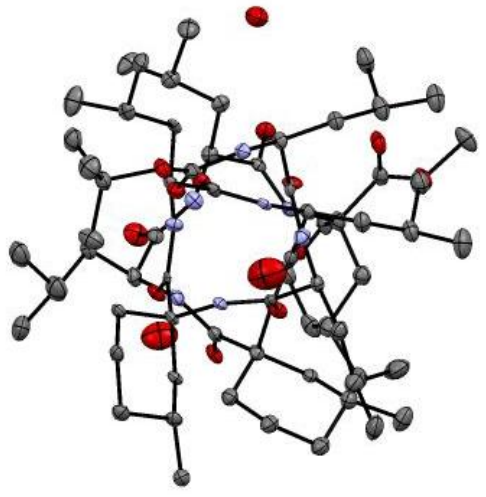

Fig. 6. Right-handed $(P) \quad \alpha$-helical structure of the $(1 R, 3 R)-\mathrm{Ac}_{6} \mathrm{c}^{3 \mathrm{M}}$ nonapeptide 5a by an X-ray crystallographic analysis. a) View perpendicular to the helical axis and b) an ORTEP drawing as viewed along the helical axis.

The $(1 S, 3 R)-\mathrm{Ac}_{6} \mathrm{c}^{3 \mathrm{M}}$ nonapeptide $\mathbf{5 b}$ was solved in the space group of $P 2_{l} 2_{l} 2_{l}$ to form a right-handed $(P) \alpha$-helical structure together with three water molecules in the asymmetric unit (Fig. 7). The average $\phi$ and $\psi$ torsion angles of residues (1-7) were $-62.3^{\circ}$ and $-42.9^{\circ}$, respectively, which corresponded to those of the ideal $(P) \alpha$-helix $\left(-57^{\circ}\right.$ and $\left.-47^{\circ}\right),{ }^{8}$ however, the $\phi$ and $\psi$ torsion angles of C-terminal $(1 S, 3 R)-\mathrm{Ac}_{6} \mathrm{c}^{3 \mathrm{M}}(9)$ and penultimate L-Leu (8) residues were distorted. The torsion angles $\left(\chi, \chi^{\prime}\right)$ relating the cyclohexyl rings to the peptide chain at residues (3), (6), and (9) showed near $-180^{\circ}$ and $+180^{\circ}$, with the $-\mathrm{NH}-$ groups at the equatorial positions of the chair form cyclohexane rings. Thus, the 3-methyl substituent and $-\mathrm{NH}-$ group of cyclohexane occupied an equatorial orientation, while the $-\mathrm{CO}-$ group pointed in an axial direction.

Five intramolecular hydrogen bonds of the $i \leftarrow i+4$ type ( $\alpha$ helix) were observed between $\mathrm{H}-\mathrm{N}(5)$ and $\mathrm{C}(1)=\mathrm{O}(1)$ $[\mathrm{N}(5) \cdots \mathrm{O}(1)=2.87 \AA]$, between $\mathrm{H}-\mathrm{N}(6)$ and $\mathrm{C}(2)=\mathrm{O}(2)$ $[\mathrm{N}(6) \cdots \mathrm{O}(2)=3.13 \AA]$, between $\mathrm{H}-\mathrm{N}(7)$ and $\mathrm{C}(3)=\mathrm{O}(3)$ $[\mathrm{N}(7) \cdots \mathrm{O}(3)=3.18 \AA]$, between $\mathrm{H}-\mathrm{N}(8)$ and $\mathrm{C}(4)=\mathrm{O}(4)$ $[\mathrm{N}(8) \cdots \mathrm{O}(4)=2.93 \AA]$, and between $\mathrm{H}-\mathrm{N}(9)$ and $\mathrm{C}(5)=\mathrm{O}(5)$ $[\mathrm{N}(9) \cdots \mathrm{O}(5)=3.17 \AA]$. The distance of $\mathrm{N}(4) \cdots \mathrm{O}(0)(3.47 \AA)$ was too long for an intramolecular hydrogen bond. The peptide $\mathrm{H}-\mathrm{N}(1), \mathrm{H}-\mathrm{N}(2)$, and $\mathrm{H}-\mathrm{N}(3)$ donors were intermolecularly hydrogen-bonded to the water acceptors $\mathrm{O}_{\mathrm{w} 1}, \mathrm{O}_{\mathrm{w} 2}$, and $\mathrm{O}_{\mathrm{w} 3}$, respectively. Furthermore, the water $\mathrm{H}-\mathrm{O}_{\mathrm{w} 1}$ donor formed bifurcated hydrogen bonds with the $\mathrm{C}(8)=\mathrm{O}(8)$ and $\mathrm{C}\left(6^{\prime}\right)=\mathrm{O}\left(6^{\prime}\right)$ acceptors, and the water $\mathrm{H}-\mathrm{O}_{\mathrm{w} 2}$ donor formed a hydrogen bond with the $\mathrm{C}(7)=\mathrm{O}(7)$ acceptor. Three water molecules formed a cluster by intermolecular hydrogen bonds.

The superimposed structures of $(1 R, 3 R)$ - and $(1 S, 3 R)-\mathrm{Ac}_{6} \mathrm{c}^{3 \mathrm{M}}$ nonapeptides are shown in Figure 8 . The peptide-backbone structures of $\mathbf{5 a}$ and $\mathbf{5 b}$ were both right-handed $(P) \alpha$-helical structures, and fit very well; however, the C-terminal methyl esters and side-chain cyclohexane structures differed. Thus, the effects of the - $\mathrm{NH}-$ group orientation of the cyclohexane chair form on its L-Leu-based peptide backbone structures was weak in the crystal state. 
a)

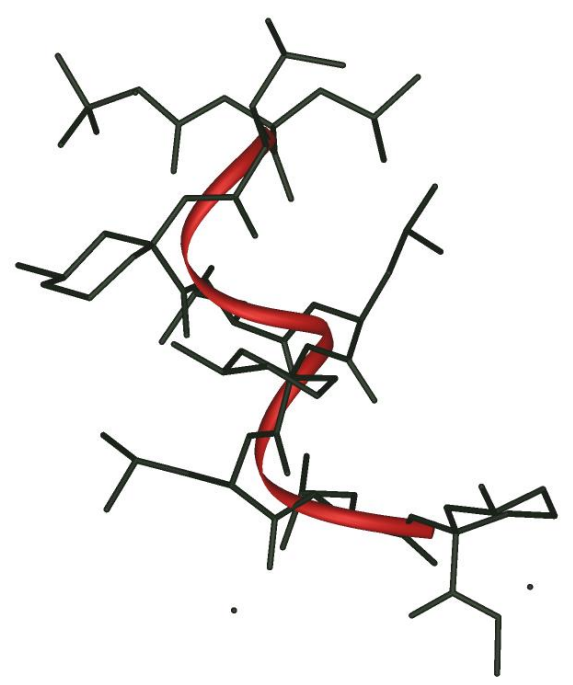

b)

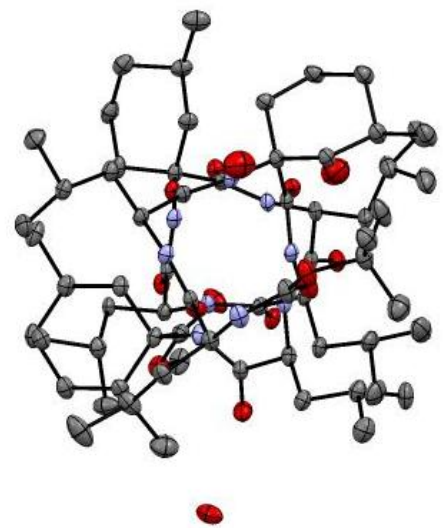

Fig. 7. Right-handed $(P) \quad \alpha$-helical structure of the $(1 S, 3 R)-\mathrm{Ac}_{6} \mathrm{c}^{3 \mathrm{M}}$ nonapeptide $\mathbf{5 b}$ by an X-ray crystallographic analysis. a) View perpendicular to the helical axis and b) an ORTEP drawing as viewed along the helical axis.

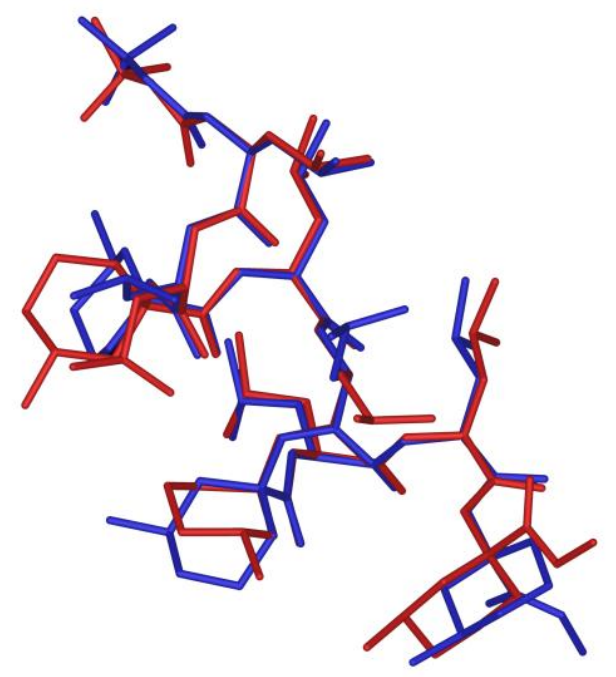

Fig. 8. Superimposed structures of $(1 R, 3 R)-$ and $(1 S, 3 R)-\mathrm{Ac}_{6} \mathrm{c}^{3 \mathrm{M}}$ nonapeptides $\mathbf{5 a}$ (red) and $\mathbf{5 b}$ (blue).
Table 1. Crystal and diffraction parameters of $(1 R, 3 R)-\mathrm{Ac}_{6} \mathrm{c}^{3 \mathrm{M}}$ and $(1 S, 3 R)-$ $\mathrm{Ac}_{6} \mathrm{c}^{3 \mathrm{M}}$ peptides $\mathbf{4 b}, \mathbf{5 a}$ and $\mathbf{5 b}$.

\begin{tabular}{|c|c|c|c|}
\hline Torsion Angle & $(1 S, 3 R)-6 \operatorname{mer} \mathbf{4 b}$ & $(1 R, 3 R)-9 \operatorname{mer} \mathbf{5 a}$ & $(1 S, 3 R)-9 \operatorname{mer} \mathbf{5 b}$ \\
\hline $\begin{array}{l}\text { empirical } \\
\text { formula }\end{array}$ & $\mathrm{C}_{46} \mathrm{H}_{80} \mathrm{~N}_{6} \mathrm{O}_{9}, \mathrm{H}_{2} \mathrm{O}$ & $\begin{array}{r}\mathrm{C}_{66} \mathrm{H}_{117} \mathrm{~N}_{9} \mathrm{O}_{12}, \\
3 \mathrm{H}_{2} \mathrm{O}\end{array}$ & $\begin{array}{r}\mathrm{C}_{66} \mathrm{H}_{117} \mathrm{~N}_{9} \mathrm{O}_{12}, \\
3 \mathrm{H}_{2} \mathrm{O}\end{array}$ \\
\hline$M r$ & 879.18 & 1282.73 & 1282.73 \\
\hline $\begin{array}{l}\text { crystal } \\
\text { diameters }[\mathrm{mm}]\end{array}$ & $0.22 \times 0.19 \times 0.04$ & $0.15 \times 0.06 \times 0.04$ & $0.20 \times 0.16 \times 0.06$ \\
\hline $\begin{array}{l}\text { Temperature } \\
{[\mathrm{K}]}\end{array}$ & 93 & 93 & 93 \\
\hline $\begin{array}{l}\text { crystal system } \\
\text { lattice } \\
\text { parameters: }\end{array}$ & orthorhombic & monoclinic & orthorhombic \\
\hline$a, b, c\left[\AA^{3}\right]$ & $\begin{array}{r}15.232,17.878 \\
18.802\end{array}$ & $\begin{array}{r}10.984,29.604 \\
12.520\end{array}$ & $\begin{array}{r}10.697,23.277 \\
30.373\end{array}$ \\
\hline$\alpha, \beta, \gamma\left[^{\circ}\right]$ & $90,90,90$ & $90,109.013,90$ & $90,90,90$ \\
\hline$V\left[\AA^{3}\right]$ & 5120 & 3849 & 7563 \\
\hline space group & $P 2_{l} 2_{l} 2_{l}$ & $P 2_{1}$ & $P 2_{l} 2_{l} 2_{l}$ \\
\hline$Z$ value & 4 & 2 & 4 \\
\hline$D$ calc $\left[\mathrm{g} / \mathrm{cm}^{3}\right]$ & 1.140 & 1.107 & 1.127 \\
\hline$\underset{\substack{\mu \\
{ }_{1}^{\mu}}}{\operatorname{MoK} \alpha \alpha)\left[\mathrm{cm}^{-}\right.}$ & 0.80 & 0.78 & 0.79 \\
\hline $\begin{array}{l}\text { no. of } \\
\text { observations (I } \\
>-10.0 \sigma \mathrm{I})\end{array}$ & 5769 & 5640 & 8499 \\
\hline no. of variables & 623 & 811 & 826 \\
\hline$R_{l}, R_{w}$ & $0.0723,0.1576$ & $0.1072,0.1738$ & $0.0849,0.2026$ \\
\hline solvent & $\mathrm{MeOH} / \mathrm{H}_{2} \mathrm{O}$ & $\mathrm{MeOH} / \mathrm{H}_{2} \mathrm{O}$ & $\mathrm{MeOH} / \mathrm{H}_{2} \mathrm{O}$ \\
\hline
\end{tabular}

Table 2. Selected torsion angles $\omega, \phi, \psi$, and $\chi\left[^{\circ}\right]$ of $(1 R, 3 R)-\mathrm{Ac}_{6} \mathrm{c}^{3 \mathrm{M}}$ and $(1 S, 3 R)-\mathrm{Ac}_{6} \mathrm{c}^{3 \mathrm{M}}$ peptides $\mathbf{4 b}, \mathbf{5 a}$ and $\mathbf{5 b}{ }^{\mathrm{a}}$

\begin{tabular}{crrr}
\hline $\begin{array}{c}\text { Torsion } \\
\text { Angle }\end{array}$ & $(1 S, 3 R)-6$ mer $\mathbf{4 b}$ & $(1 R, 3 R)-9$ mer $\mathbf{5 a}$ & $(1 S, 3 R)-9$ mer $\mathbf{5 b}$ \\
\hline$\omega 0$ & $---^{\mathrm{b}}$ & -169.2 & -178.4 \\
$\phi 1$ & $---^{\mathrm{b}}$ & -55.5 & -65.1 \\
$\psi 1$ & -40.8 & -47.5 & -45.5 \\
$\omega 1$ & -179.3 & -174.3 & -173.1 \\
$\phi 2$ & -55.3 & -63.9 & -61.0 \\
$\psi 2$ & -43.5 & -44.2 & -43.4 \\
$\omega 2$ & 176.7 & 178.7 & 176.4 \\
$\phi 3$ & -45.7 & -54.0 & -50.7 \\
$\psi 3$ & -49.0 & -47.5 & -50.8 \\
$\omega 3$ & -171.8 & -179.2 & -175.5 \\
$\phi 4$ & -70.8 & -60.9 & -66.6 \\
$\psi 4$ & -13.6 & -41.1 & -38.8 \\
$\omega 4$ & -176.9 & 180.0 & 178.4 \\
$\phi 5$ & -110.9 & -61.0 & -59.0 \\
$\psi 5$ & 2.7 & -47.4 & -47.0 \\
$\omega 5$ & -172.6 & -177.1 & -177.3 \\
$\phi 6$ & -56.2 & -54.3 & -59.2 \\
$\psi 6$ & -54.5 & -39.2 & -40.1 \\
$\omega 6$ & -174.7 & -179.3 & -177.9 \\
$\phi 7$ & --- & -73.6 & -74.6 \\
$\psi 7$ & --- & -38.0 & -34.8 \\
$\omega 7$ & --- & -169.9 & -164.7 \\
$\phi 8$ & --- & -91.3 & -102.5 \\
$\psi 8$ & --- & -13.4 & -2.9 \\
$\omega 8$ & --- & -176.7 & 169.5 \\
$\phi 9$ & --- & 64.4 & -59.1 \\
$\psi 9$ & --- & -169.8 & 139.0 \\
$\omega 9$ & & & 176.0 \\
& & &
\end{tabular}




$\begin{array}{rrrrr} & \chi 1 & 178.7 & 179.1 & -178.2 \\ & \chi^{2} & -175.3 & 178.3 & -59.4 \\ & \chi^{3} & -174.8 & -67.0 & -175.7 \\ 1 & \chi^{3} & 169.0 & 66.3 & 168.4 \\ 2 & \chi^{4} & -53.6 & -64.4 & -62.3 \\ 3 & \chi 5 & -56.6 & 179.6 & -60.0 \\ 4 & \chi 6 & -175.7 & -69.0 & -170.3 \\ 5 & \chi 6 & 169.0 & 66.8 & 163.5 \\ 6 & \chi 7 & --- & -65.9 & -77.4 \\ 7 & \chi 8 & --- & -69.7 & -62.0 \\ 8 & \chi 9 & --- & -64.9 & -171.6 \\ 9 & \chi 9 & --- & 69.3 & 165.3 \\ 10 & \chi 9^{\prime} & & & \end{array}$

a The number of amino acid residues begins at the $N$-terminus of the peptide chain.

${ }^{\mathrm{b}}$ Disordered.

Table 3. Intra- and intermolecular $\mathrm{H}$-bond parameters for $(1 R, 3 R)-\mathrm{Ac}_{6} \mathrm{c}^{3 \mathrm{M}}$ and $(1 S, 3 R)-\mathrm{Ac}_{6} \mathrm{c}^{3 \mathrm{M}}$ peptides $\mathbf{4 b}, \mathbf{5 a}$ and $\mathbf{5 b}$.

\begin{tabular}{|c|c|c|c|c|c|}
\hline Peptide & $\begin{array}{l}\text { Donor } \\
\text { D-H }\end{array}$ & $\begin{array}{l}\text { Acceptor } \\
\text { A }\end{array}$ & $\begin{array}{l}\text { Distance } \\
{[\AA]} \\
\text { D } \cdots A\end{array}$ & 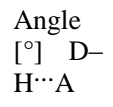 & $\begin{array}{l}\text { Symmetry } \\
\text { operations }\end{array}$ \\
\hline \multicolumn{6}{|c|}{ Boc- $\left\{\text { L-Leu-L-Leu- }\left[(1 S, 3 R)-\mathrm{Ac}_{6} \mathrm{c}^{3 \mathrm{M}}\right]\right\}_{2}-\mathrm{OMe}(\mathbf{4 b})$} \\
\hline & $\mathrm{N}_{4}-\mathrm{H}$ & $\mathrm{O}_{1}$ & 2.90 & 124 & $\mathrm{x}, \mathrm{y}, \mathrm{z}$ \\
\hline & $\mathrm{N}_{5}-\mathrm{H}$ & $\mathrm{O}_{1}$ & $3.32^{\mathrm{a}}$ & 122 & $\mathrm{x}, \mathrm{y}, \mathrm{z}$ \\
\hline & $\mathrm{N}_{5}-\mathrm{H}$ & $\mathrm{O}_{2}$ & 2.92 & 153 & $\mathrm{x}, \mathrm{y}, \mathrm{z}$ \\
\hline & $\mathrm{N}_{6}-\mathrm{H}$ & $\mathrm{O}_{2}$ & 3.19 & $106^{\mathrm{b}}$ & $\mathrm{x}, \mathrm{y}, \mathrm{z}$ \\
\hline & $\mathrm{N}_{6}-\mathrm{H}$ & $\mathrm{O}_{3}$ & $3.37^{\mathrm{a}}$ & 167 & $\mathrm{x}, \mathrm{y}, \mathrm{z}$ \\
\hline & $\mathrm{N}_{1}-\mathrm{H}$ & $\mathrm{O}_{4}$ & 2.87 & 129 & $\begin{array}{l}1 / 2-\mathrm{x} \\
-\mathrm{y}, 1 / 2+\mathrm{z}\end{array}$ \\
\hline & $\mathrm{N}_{2}-\mathrm{H}$ & $\mathrm{O}_{4}$ & 2.98 & 172 & $\begin{array}{l}1 / 2-x \\
-y, 1 / 2+z\end{array}$ \\
\hline & $\mathrm{N}_{3}-\mathrm{H}$ & $\mathrm{O}_{\mathrm{w}}$ & 2.98 & 151 & $\begin{array}{l}-\mathrm{x}, 1 / 2+\mathrm{y}, 1 / 2- \\
\mathrm{z}\end{array}$ \\
\hline & $\mathrm{O}_{\mathrm{w}}-\mathrm{H}$ & $\mathrm{O}_{5}$ & 2.92 & 174 & $\mathrm{x}, \mathrm{y}, \mathrm{z}$ \\
\hline
\end{tabular}

Boc- $\left\{\text { L-Leu-L-Leu- }\left[(1 R, 3 R)-\mathrm{Ac}_{6} \mathrm{c}^{3 \mathrm{M}}\right]\right\}_{3}-\mathrm{OMe}(\mathbf{5 a})$

$\begin{array}{lllll}\mathrm{N}_{4}-\mathrm{H} & \mathrm{O}_{0} & 3.14 & 166 & \mathrm{x}, \mathrm{y}, \mathrm{z} \\ \mathrm{N}_{5}-\mathrm{H} & \mathrm{O}_{1} & 2.93 & 154 & \mathrm{x}, \mathrm{y}, \mathrm{z} \\ \mathrm{N}_{6}-\mathrm{H} & \mathrm{O}_{2} & 3.07 & 168 & \mathrm{x}, \mathrm{y}, \mathrm{z} \\ \mathrm{N}_{7}-\mathrm{H} & \mathrm{O}_{3} & 3.19 & 153 & \mathrm{x}, \mathrm{y}, \mathrm{z} \\ \mathrm{N}_{8}-\mathrm{H} & \mathrm{O}_{4} & 2.88 & 141 & \mathrm{x}, \mathrm{y}, \mathrm{z} \\ \mathrm{N}_{9}-\mathrm{H} & \mathrm{O}_{5} & 3.00 & 140 & \mathrm{x}, \mathrm{y}, \mathrm{z} \\ \mathrm{N}_{1}-\mathrm{H} & \mathrm{O}_{8}, & 2.95 & 146 & 1-\mathrm{x},-1 / 2+\mathrm{y}, \\ \mathrm{N}_{2}-\mathrm{H} & \mathrm{O}_{\mathrm{w} 3} & 2.86 & 152 & \mathrm{x}, \mathrm{y}, \mathrm{z} \\ \mathrm{O}_{\mathrm{w} 1}-\mathrm{H} & \mathrm{O}_{8} & 2.81 & 158 & \mathrm{x}, \mathrm{y}, \mathrm{z} \\ \mathrm{O}_{\mathrm{w1}}-\mathrm{H} & \mathrm{O}_{6} & 2.90 & 169 & -1+\mathrm{x}, \mathrm{y}, \mathrm{z} \\ \mathrm{O}_{\mathrm{w} 2}-\mathrm{H} & \mathrm{O}_{6} & 2.99 & 169 & \mathrm{x}, \mathrm{y}, \mathrm{z} \\ \mathrm{O}_{\mathrm{w} 2}-\mathrm{H} & \mathrm{O}_{7} & 2.77 & 150 & \mathrm{x}, \mathrm{y}, \mathrm{z} \\ \mathrm{O}_{\mathrm{w} 3}-\mathrm{H} & \mathrm{O}_{\mathrm{w} 1}, & 2.77 & 147 & 1-\mathrm{x},-1 / 2+\mathrm{y}, \\ \mathrm{O}_{\mathrm{w} 3}-\mathrm{H} & \mathrm{O}_{\mathrm{w} 2}, & 2.83 & 153 & 2-\mathrm{x},-1 / 2+\mathrm{y}, \\ & & & & -\mathrm{z}\end{array}$

Boc- $\left\{\text { L-Leu-L-Leu- }\left[(1 S, 3 R)-\mathrm{Ac}_{6} \mathrm{c}^{3 \mathrm{M}}\right]\right\}_{3}-\mathrm{OMe}(\mathbf{5 b})$

$\begin{array}{lllll}\mathrm{N}_{4}-\mathrm{H} & \mathrm{O}_{0} & 3.47^{\mathrm{a}} & 161 & \mathrm{x}, \mathrm{y}, \mathrm{z} \\ \mathrm{N}_{5}-\mathrm{H} & \mathrm{O}_{1} & 2.87 & 159 & \mathrm{x}, \mathrm{y}, \mathrm{z}\end{array}$

$\begin{array}{lllll}\mathrm{N}_{6}-\mathrm{H} & \mathrm{O}_{2} & 3.13 & 169 & \mathrm{x}, \mathrm{y}, \mathrm{z} \\ \mathrm{N}_{7}-\mathrm{H} & \mathrm{O}_{3} & 3.18 & 151 & \mathrm{x}, \mathrm{y}, \mathrm{z} \\ \mathrm{N}_{8}-\mathrm{H} & \mathrm{O}_{4} & 2.93 & 134 & \mathrm{x}, \mathrm{y}, \mathrm{z} \\ \mathrm{N}_{9}-\mathrm{H} & \mathrm{O}_{5} & 3.17 & 141 & \mathrm{x}, \mathrm{y}, \mathrm{z} \\ \mathrm{N}_{1}-\mathrm{H} & \mathrm{O}_{\mathrm{w} 1}, & 2.91 & 171 & \begin{array}{l}3 / 2-\mathrm{x}, 1-\mathrm{y}, \\ \mathrm{N}\end{array} \\ \mathrm{N}_{1}-\mathrm{H} & \mathrm{O}_{\mathrm{w} 2}, & 2.95 & 1 / 2+\mathrm{z} \\ & \mathrm{O}_{\mathrm{w} 2}, & 2.78 & 179 & 1 / 2-\mathrm{x}, 1-\mathrm{y}, \\ \mathrm{N}_{2}-\mathrm{H} & \mathrm{O}^{\mathrm{b}} & 1 / 2-\mathrm{z}, 1-\mathrm{y}, \\ \mathrm{N}_{3}-\mathrm{H} & \mathrm{O}_{\mathrm{w} 3} & 3.07 & 167 & -1 / 2+\mathrm{z}, \mathrm{y}, \mathrm{z} \\ \mathrm{O}_{\mathrm{w} 1}-\mathrm{H} & \mathrm{O}_{8} & 2.81 & 171 & \mathrm{x}, \mathrm{y}, \mathrm{z} \\ \mathrm{O}_{\mathrm{w} 2}-\mathrm{H} & \mathrm{O}_{7} & 2.59 & 137 & \mathrm{x}, \mathrm{y}, \mathrm{z} \\ \mathrm{O}_{\mathrm{w} 2}-\mathrm{H} & \mathrm{O}_{\mathrm{w} 1}, & 2.74 & 156 & -1+\mathrm{x}, \mathrm{y}, \mathrm{z} \\ \mathrm{O}_{\mathrm{w} 1}-\mathrm{H} & \mathrm{O}_{6} & 2.82 & 167 & -1+\mathrm{x}, \mathrm{y}, \mathrm{z} \\ \mathrm{O}_{\mathrm{w} 3}-\mathrm{H} & \mathrm{O}_{\mathrm{w} 2} & 2.71 & 145 & 1 / 2-\mathrm{x}, 1-\mathrm{y}, \\ & & & & -1 / 2+\mathrm{z}\end{array}$

${ }^{\text {a }}$ The distance is a bit long or too long for an intramolecular hydrogen bond.

${ }^{\mathrm{b}}$ The angle $\mathrm{N}-\mathrm{H} \cdots \mathrm{O}$ is too small for a hydrogen bond.

The reported theoretical calculation of $\mathrm{Ac}^{-\mathrm{Ac}_{6} \mathrm{c}-\mathrm{NHMe}}$ showed the torsion angles $\phi \pm 48^{\circ} ; \psi \pm 60^{\circ 4 \mathrm{~b}}$ ( or $\phi \pm 40^{\circ} ; \psi \pm 80^{\circ 4 \mathrm{c}}$ ) as a minimum energy structure when the amino - $\mathrm{NH}-$ group of the cyclohexane amino acid occupied the equatorial position. However, the X-ray crystallographic analysis of the $(1 S, 3 R)-\mathrm{Ac}_{6} \mathrm{c}$ heteropeptides $\mathbf{4 b}$ and $\mathbf{5 b}$ did not show large $\psi$ torsion angles, as calculated. The $(1 R, 3 R)-\mathrm{Ac}_{6} \mathrm{c}^{3 \mathrm{M}}$ and $(1 S, 3 R)-\mathrm{Ac}_{6} \mathrm{c}^{3 \mathrm{M}}$ nonapeptides $\mathbf{5 a}$ and $\mathbf{5 b}$ both formed almost similar right-handed $(P) \alpha$-helical structures in the crystal state. These results may be attributed to cyclic dAA-containing L-Leu-based nonapeptides preferring to form $\alpha$-helical structures over the $3_{10}$-helical structures of Aib-containing peptides. ${ }^{9}$ We previously reported that a $(1 R, 3 R)-\mathrm{Ac}_{6} \mathrm{c}^{3 \mathrm{M}}$ homohexapeptide formed right-handed $(P)$ and left-handed $(M) 33_{10}$-helical structures, while a $(1 S, 3 R)-\mathrm{Ac}_{6} \mathrm{c}^{3 \mathrm{M}}$ homohexapeptide formed $(P)$ and $(M) \alpha$-helical structures in the crystal state. In comparison, the properties of the $\alpha$-helical formation of $(1 S, 3 R)-\mathrm{Ac}_{6} \mathrm{c}^{3 \mathrm{M}}$ were stronger than those of $(1 R, 3 R)$ $\mathrm{Ac}_{6} \mathrm{c}^{3 \mathrm{M}}$.

In the CD spectra of the nonapeptides $\mathbf{5 a}$ and $\mathbf{5 b}$ in TFE solution, the intensities of the negative maxima (208 $\mathrm{nm}$ and 222 $\mathrm{nm})$ of the $(1 S, 3 R)-\mathrm{Ac}_{6} \mathrm{c}^{3 \mathrm{M}}$ peptide $\mathbf{5} \mathbf{b}$ were stronger than those of the $(1 R, 3 R)-\mathrm{Ac}_{6} \mathrm{c}^{3 \mathrm{M}}$ peptide $\mathbf{5 b}$. Thus, the $(1 S, 3 R)-\mathrm{Ac}_{6} \mathrm{c}^{3 \mathrm{M}}$ peptide 5b may be more (right-handed, $P)$ helical than the $(1 R, 3 R)$ $\mathrm{Ac}_{6} \mathrm{c}^{3 \mathrm{M}}$ peptide $\mathbf{5 a}$ in TFE solution.

The results of the conformational analysis between solution and the crystal state were slightly different. These differences may have been due to the solvents used in the conformational study being different between the solution analysis $\left(\mathrm{CDCl}_{3}\right.$ or TFE) and crystal state (re-crystallized solvent: $\mathrm{MeOH} / \mathrm{H}_{2} \mathrm{O}$ ). ${ }^{16}$ Also, the crystal packing forces and nucleation events in crystallization may affect the conformation in the crystal state.

The heteropeptides studied had the - L-Leu-L-Leu- $\mathrm{Ac}_{6} \mathrm{c}^{3 \mathrm{M}}$ sequence, in which the L-Leu content was $66 \%$ and $\mathrm{Ac}_{6} \mathrm{c}^{3 \mathrm{M}}$ content was $33 \%$. Thus, the effects of L-Leu properties on the screw sense of its peptide secondary structure were stronger than those of $\mathrm{Ac}_{6} \mathrm{c}^{3 \mathrm{M}}$ because these peptides exclusively formed righthanded helices due to L-Leu chirality. Four stereoisomers, including a pair of enantiomers, may exist in the structure of $\mathrm{Ac}_{6} \mathrm{c}^{3 \mathrm{M}}$. Therefore, if other stereo-isomeric $\mathrm{Ac}_{6} \mathrm{c}^{3 \mathrm{M}}$ were incorporated into the L-Leu sequence, the peptides may form different secondary structures due to the effects of 
stereochemistry as well as the amino $-\mathrm{NH}-$ group equatorial or axial influence.

\section{Conclusion}

We prepared L-Leu-based peptides having $(1 R, 3 R)-\mathrm{Ac}_{6} \mathrm{c}^{3 \mathrm{M}}$ and $(1 S, 3 R)-\mathrm{Ac}_{6} \mathrm{c}^{3 \mathrm{M}}$, respectively, and studied their preferred conformations in solution and in the crystal state.

In L-Leu-based peptides, the equatorial or axial orientation of the - $\mathrm{NH}$ - group of side-chain cyclohexane was controlled using a 3-methyl substituent of chiral cyclic $\mathrm{Ac}_{6} \mathrm{c}^{3 \mathrm{M}}$. Based on the CD spectra, the $(1 S, 3 R)-\mathrm{Ac}_{6} \mathrm{c}^{3 \mathrm{M}}$ nonapeptide $\mathbf{5 b}$ may be more (righthanded, $P$ ) helical than the $(1 R, 3 R)-\mathrm{Ac}_{6} \mathrm{c}^{3 \mathrm{M}}$ nonapeptide $\mathbf{5 a}$ in TFE solution; however, in the crystal state, the $(1 R, 3 R)-\mathrm{Ac}_{6} \mathrm{c}^{3 \mathrm{M}}$ and $(1 S, 3 R)-\mathrm{Ac}_{6} \mathrm{c}^{3 \mathrm{M}}$ nonapeptides $\mathbf{5 a}$ and $\mathbf{5 b}$ both formed almost similar right-handed $(P) \quad \alpha$-helical structures in the peptide backbone. The differences of conformational study between solution and the crystal state may have been due to the different solvents, and also the crystal packing forces and nucleation events in crystallization. Thus, the effects of the equatorial or axial orientation of the $-\mathrm{NH}-$ group of cyclic $\mathrm{Ac}_{6} \mathrm{c}$ on the secondary structures of its peptides were not strong.

These results may be useful for designing chiral peptide catalysts for enantioselective reactions, ${ }^{17,18}$ which is under way in our group. ${ }^{19}$

\section{Experimental Section}

\subsection{General}

Optical rotations $[\alpha]_{D}$ were measured using a $1.0-\mathrm{dm}$ cell. Circular dichroism spectra (CD) were measured using a $1.0-\mathrm{mm}$ path length cell. Infrared spectra (IR) were recorded for conventional measurements $(\mathrm{KBr})$, and the solution $\left(\mathrm{CDCl}_{3}\right)$ method was performed using the $0.1-\mathrm{mm}$ path length of an $\mathrm{NaCl}$ cell. ${ }^{1} \mathrm{H}$ NMR spectra were determined at 400 or $500 \mathrm{MHz}$ at room temperature. HRMS(ESI) spectra were measured in the ToF mode.

\subsection{Synthesis of L-Leu-based peptides}

4.2.1. Boc-L-Leu-L-Leu-(1R,3R)-Ac $c_{6} C^{3 M}-O M e \quad(2 a) . \quad \mathrm{A}$ mixture of Boc-L-Leu-L-Leu-OH (1.62 g, $4.70 \mathrm{mmol})$, amine 1a ${ }^{7}$ $(670 \mathrm{mg}, 3.91 \mathrm{mmol}), \mathrm{EDCI} \cdot \mathrm{HCl}(900 \mathrm{mg}, 4.70 \mathrm{mmol})$, and $\mathrm{HOBt} \cdot \mathrm{H}_{2} \mathrm{O}(640 \mathrm{mg}, 4.70 \mathrm{mmol})$ in $\mathrm{MeCN}(20 \mathrm{~mL})$ was stirred at $0{ }^{\circ} \mathrm{C}$ for $30 \mathrm{~min}$. After being stirred at room temperature for $17 \mathrm{~h}$, the solution was evaporated, diluted with EtOAc, washed with $1 \mathrm{M}$ aqueous $\mathrm{HCl}$, water, $5 \%$ aqueous $\mathrm{NaHCO}_{3}$, and brine, and then dried over $\mathrm{MgSO}_{4}$. The removal of the solvent afforded a solid, which was purified by column chromatography on silica gel. The fraction eluted with $30 \%$ EtOAc in $n$-hexane afforded the tripeptide 2a $(1.67 \mathrm{~g}, 86 \%)$ as crystals: $\mathrm{mp} 163-165{ }^{\circ} \mathrm{C}$; $[\alpha]_{\mathrm{D}}^{25}-76.3\left(\mathrm{c} 1.00, \mathrm{CHCl}_{3}\right)$; IR $(\mathrm{KBr}) \vee 3331(\mathrm{br}), 2955,1745$, 1718, 1647, $1528 \mathrm{~cm}^{-1} ;{ }^{1} \mathrm{H}$ NMR (400 MHz, $\left.\mathrm{CDCl}_{3}\right) \delta 6.72(\mathrm{~s}$, $1 \mathrm{H}), 6.51(\mathrm{~d}, J=6.9 \mathrm{~Hz}, 1 \mathrm{H}), 4.91(\mathrm{br} \mathrm{d}, J=6.0 \mathrm{~Hz}, 1 \mathrm{H}), 4.42$ $(\mathrm{m}, 1 \mathrm{H}), 4.09(\mathrm{~m}, 1 \mathrm{H}), 3.66(\mathrm{~s}, 3 \mathrm{H}), 2.19(\mathrm{~d}, J=12.8 \mathrm{~Hz}, 1 \mathrm{H})$, $2.09(\mathrm{~d}, J=12.7 \mathrm{~Hz}, 1 \mathrm{H}), 1.79-1.46(\mathrm{~m}, 10 \mathrm{H}), 1.45(\mathrm{~s}, 9 \mathrm{H})$, $1.41-1.27(\mathrm{~m}, 2 \mathrm{H}), 0.99-0.82(\mathrm{~m}, 16 \mathrm{H}) ;{ }^{13} \mathrm{C} \mathrm{NMR}(100 \mathrm{MHz}$, $\left.\mathrm{CDCl}_{3}\right): \delta 174.5,172.9,170.8,155.8,80.4,59.4,53.2,52.1,51.5$, $40.9,40.2,39.6,33.9,31.1,28.2$ (3C), 27.4, 24.8, 24.6, 22.89, $22.85,22.3,22.0,21.8,21.1$; $\operatorname{HRMS}(\mathrm{ESI}):[\mathrm{M}+\mathrm{Na}]^{+}$, found 520.3369. $\mathrm{C}_{26} \mathrm{H}_{47} \mathrm{~N}_{3} \mathrm{O}_{6} \mathrm{Na}$ requires 520.3363.
Tripeptide $\mathbf{2 b}$ was prepared from $\mathbf{1 b}$ in a manner similar to that described for the preparation of tripeptide 2a: $88 \%$; crystals; $\mathrm{mp}$ $174-176^{\circ} \mathrm{C} ;[\alpha]_{\mathrm{D}}^{25}-63.5\left(c 1.00, \mathrm{CHCl}_{3}\right)$; IR (KBr) v 3309 (br), 2955, 1748, 1651, $1524 \mathrm{~cm}^{-1} ;{ }^{1} \mathrm{H}$ NMR $\left(400 \mathrm{MHz}, \mathrm{CDCl}_{3}\right) \delta 6.80$ (s, 1H), 6.68 (br d, $J=7.8 \mathrm{~Hz}, 1 \mathrm{H}), 5.07$ (br d, $J=5.3 \mathrm{~Hz}, 1 \mathrm{H})$, $4.38(\mathrm{~m}, 1 \mathrm{H}), 4.11(\mathrm{~m}, 1 \mathrm{H}), 3.68(\mathrm{~s}, 3 \mathrm{H}), 2.45-2.34(\mathrm{~m}, 2 \mathrm{H})$, 1.77-1.57 (m, 8H), 1.55-1.46 (m, 3H), $1.44(\mathrm{~s}, 9 \mathrm{H}), 1.26(\mathrm{~m}$, $1 \mathrm{H}), 0.98-0.76(\mathrm{~m}, 16 \mathrm{H}) ;{ }^{13} \mathrm{C}$ NMR $\left(100 \mathrm{MHz}, \mathrm{CDCl}_{3}\right) \delta 173.2$, 172.7, 170.6, 155.7, 80.2, 59.1, 53.3, 51.9, 51.4, 42.6, 40.9, 40.2, $34.1,34.0,28.6,28.2$ (3C), 24.7, 24.6, 22.9, 22.8, 22.32, 22.29, 21.9 (2C); HRMS(ESI): $[\mathrm{M}+\mathrm{Na}]^{+}, \quad$ found 520.3372. $\mathrm{C}_{26} \mathrm{H}_{47} \mathrm{~N}_{3} \mathrm{O}_{6} \mathrm{Na}$ requires 520.3363 .

4.2.3. Boc-L-Leu-L-Leu-(IR,3R)-Ac $c_{6} c^{3 M}-O H(3 a)$. A solution of tripeptide 2a $(600 \mathrm{mg}, 1.20 \mathrm{mmol})$ in $\mathrm{MeOH}(200 \mathrm{~mL})$ and $0.1 \mathrm{M}$ aqueous $\mathrm{NaOH}(600 \mathrm{~mL})$ was stirred at $40{ }^{\circ} \mathrm{C}$ for 5 days. Then, the solution was acidified with $1 \mathrm{M}$ aqueous $\mathrm{HCl}$, and $\mathrm{MeOH}$ was evaporated. The aqueous phase was extracted with $\mathrm{CHCl}_{3}$, and dried over $\mathrm{MgSO}_{4}$. The removal of the solvent afforded a crude carboxylic acid 3a (560 mg, quantitative) as a solid, which was used for the next step without further purification.

4.2.4. Boc-[L-Leu-L-Leu-(1R,3R)-Ac $\left.c_{6} \mathrm{C}^{3 M}\right]_{2}$-OMe (4a). Concentrated $\mathrm{HCl}(3 \mathrm{~mL})$ was added to the stirred solution of $2 \mathbf{a}$ $(560 \mathrm{mg}, 1.13 \mathrm{mmol})$ in EtOAc $(9 \mathrm{~mL})$ and $\mathrm{MeOH}(1 \mathrm{~mL})$ at 0 ${ }^{\circ} \mathrm{C}$, and the solution was stirred at room temperature. After being stirred for $2 \mathrm{~h}$, the solution was neutralized with $5 \%$ aqueous $\mathrm{NaHCO}_{3}$, extracted with $\mathrm{CHCl}_{3}$, and dried over $\mathrm{MgSO}_{4}$. The removal of the solvent afforded a crude amine $(420 \mathrm{mg}, 94 \%)$ as a solid, which was used for the next step without further purification. A solution of crude carboxylic acid 3a $(97.0 \mathrm{mg}$, $0.200 \mathrm{mmol})$, the crude amine $(73.0 \mathrm{mg}, 0.184 \mathrm{mmol}), \mathrm{EDC} \cdot \mathrm{HCl}$ (38 mg, $0.20 \mathrm{mmol}$ ), and $\mathrm{HOBt} \cdot \mathrm{H}_{2} \mathrm{O}(27 \mathrm{mg}, 0.20 \mathrm{mmol})$ in $\mathrm{MeCN}(5 \mathrm{~mL})$ was stirred at $0{ }^{\circ} \mathrm{C}$ for $30 \mathrm{~min}$, and at room temperature for $18 \mathrm{~h}$. Then, the reaction mixture was diluted with EtOAc, washed with $1 \mathrm{M}$ aqueous $\mathrm{HCl}$, water, $5 \%$ aqueous $\mathrm{NaHCO}_{3}$, and brine, and then dried over $\mathrm{Na}_{2} \mathrm{SO}_{4}$. The removal of the solvent afforded a solid, which was purified by column chromatography on silica gel (50\% EtOAc in $n$-hexane) to give the hexapeptide $4 \mathbf{a}(134 \mathrm{mg}, 85 \%)$ as crystals: $\mathrm{mp} 235-237{ }^{\circ} \mathrm{C}$; $[\alpha]^{25}-29.7\left(c 1.00, \mathrm{CHCl}_{3}\right)$; IR (KBr) $\vee 3370(\mathrm{br}), 2957,1745$ (w), 1720 (w), 1649 (br), $1527 \mathrm{~cm}^{-1} ;{ }^{1} \mathrm{H}$ NMR (400 MHz, $\mathrm{CDCl}_{3}$ ) $\delta 7.46(\mathrm{~d}, J=8.3 \mathrm{~Hz}, 1 \mathrm{H}), 7.21(\mathrm{~d}, J=5.5 \mathrm{~Hz}, 1 \mathrm{H}), 6.86(\mathrm{~s}, 2 \mathrm{H})$, $6.70(\mathrm{~s}, 1 \mathrm{H}), 4.96(\mathrm{br} \mathrm{d}, J=3.0 \mathrm{~Hz}, 1 \mathrm{H}), 4.41(\mathrm{~m}, 1 \mathrm{H}), 4.28(\mathrm{~m}$, $1 \mathrm{H}), 3.97-3.88(\mathrm{~m}, 2 \mathrm{H}), 3.66(\mathrm{~s}, 3 \mathrm{H}), 2.40-2.13(\mathrm{~m}, 2 \mathrm{H}), 1.84-$ $1.56(\mathrm{~m}, 23 \mathrm{H}), 1.48(\mathrm{~s}, 9 \mathrm{H}), 1.33-1.23(\mathrm{~m}, 3 \mathrm{H}), 1.03-0.83(\mathrm{~m}$, $32 \mathrm{H})$; HRMS(ESI): $[\mathrm{M}+\mathrm{Na}]^{+}$, found 885.6034. $\mathrm{C}_{46} \mathrm{H}_{82} \mathrm{~N}_{6} \mathrm{O}_{9} \mathrm{Na}$ requires 885.6041 .

4.2.5. Boc-[L-Leu-L-Leu-(1S,3R)-Ac $\left.c_{6} c^{3 M}\right]_{2}-O M e \quad(4 b)$. Hexapeptide $\mathbf{4 b}$ was prepared from $\mathbf{2 b}$ in a manner similar to that described for the preparation of tripeptide 4a: $80 \%$; crystals; $\mathrm{mp}$ $211-213{ }^{\circ} \mathrm{C} ;[\alpha]^{26}{ }_{\mathrm{D}}-22.6\left(c 1.00, \mathrm{CHCl}_{3}\right)$; IR (KBr) $\vee 3323(\mathrm{br})$, 2957, 1746, 1728, 1651 (br), $1526 \mathrm{~cm}^{-1} ;{ }^{1} \mathrm{H}$ NMR $(400 \mathrm{MHz}$, $\left.\mathrm{CDCl}_{3}\right) \delta 7.37(\mathrm{~d}, J=8.8 \mathrm{~Hz}, 1 \mathrm{H}), 7.25(\mathrm{~s}, 1 \mathrm{H}), 7.05(\mathrm{~s}, 1 \mathrm{H}), 6.94$ $(\mathrm{d}, J=5.8 \mathrm{~Hz}, 1 \mathrm{H}), 6.52(\mathrm{br} \mathrm{d}, J=4.4 \mathrm{~Hz}, 1 \mathrm{H}), 4.97(\mathrm{~d}, J=2.9$ $\mathrm{Hz}, 1 \mathrm{H}), 4.41(\mathrm{~m}, 1 \mathrm{H}), 4.12(\mathrm{~m}, 1 \mathrm{H}), 3.96-3.88(\mathrm{~m}, 2 \mathrm{H}), 3.69$ (s, $3 \mathrm{H}), 2.85(\mathrm{~d}, J=11.7 \mathrm{~Hz}, 1 \mathrm{H}), 2.42(\mathrm{~d}, J=12.7 \mathrm{~Hz}, 2 \mathrm{H}), 2.27$ $(\mathrm{m}, 1 \mathrm{H}), 1.92(\mathrm{~d}, J=12.2 \mathrm{~Hz}, 1 \mathrm{H}), 1.84-1.54(\mathrm{~m}, 20 \mathrm{H}), 1.50(\mathrm{~s}$, 9H), 1.34-1.24 (m, 3H), 1.04-0.78 (m, 32H); HRMS(ESI): $[\mathrm{M}+\mathrm{Na}]^{+}$, found 885.6016. $\mathrm{C}_{46} \mathrm{H}_{82} \mathrm{~N}_{6} \mathrm{O}_{9} \mathrm{Na}$ requires 885.6041.

4.2.6. Boc-[L-Leu-L-Leu-(1R,3R)-Ac $\left.c_{6} c^{3 M}\right]_{3}$-OMe (5a). Nonapeptide 5a was prepared from $\mathbf{4 a}$ and $\mathbf{3 a}$ in a manner similar to that described for the preparation of hexapeptide 4a: $76 \%$; crystals; mp $222{ }^{\circ} \mathrm{C}$ (decomp.); $[\alpha]^{25}{ }_{\mathrm{D}}-27.5$ (c 1.00, $\mathrm{CHCl}_{3}$ ); IR 
$(\mathrm{KBr})$ v 3329 (br), 2955, 1744, 1654, $1524 \mathrm{~cm}^{-1} ;{ }^{1} \mathrm{H}$ NMR (400 $\left.\mathrm{MHz}, \mathrm{CDCl}_{3}\right) \delta 7.78(\mathrm{~d}, J=4.2 \mathrm{~Hz}, 1 \mathrm{H}), 7.56(\mathrm{~d}, J=7.8 \mathrm{~Hz}$, $1 \mathrm{H}), 7.49(\mathrm{~d}, J=5.4 \mathrm{~Hz}, 1 \mathrm{H}), 7.31(\mathrm{~d}, J=6.8 \mathrm{~Hz}, 1 \mathrm{H}), 7.03(\mathrm{~s}$, 1 1H), $6.98(\mathrm{~s}, 1 \mathrm{H}), 6.96(\mathrm{~s}, 1 \mathrm{H}), 6.92(\mathrm{~s}, 1 \mathrm{H}), 5.43(\mathrm{br} \mathrm{s}, 1 \mathrm{H}), 4.35$ $2(\mathrm{~m}, 1 \mathrm{H}), 4.27(\mathrm{~m}, 1 \mathrm{H}), 4.03-3.84(\mathrm{~m}, 4 \mathrm{H}), 3.65(\mathrm{~s}, 3 \mathrm{H}), 2.47(\mathrm{~d}, J$ $=13.6 \mathrm{~Hz}, 1 \mathrm{H}), 2.33(\mathrm{t}, J=12.6 \mathrm{~Hz}, 2 \mathrm{H}), 2.19(\mathrm{~d}, J=12.0 \mathrm{~Hz}$, $1 \mathrm{H}), 2.00(\mathrm{~d}, J=11.7 \mathrm{~Hz}, 1 \mathrm{H}), 1.92-1.55(\mathrm{~m}, 34 \mathrm{H}), 1.49(\mathrm{~s}, 9 \mathrm{H})$, $1.31-1.23(\mathrm{~m}, 3 \mathrm{H}), 1.04-0.84(\mathrm{~m}, 48 \mathrm{H})$; HRMS(ESI): $[\mathrm{M}+\mathrm{H}]^{+}$, found 1228.8865. $\mathrm{C}_{66} \mathrm{H}_{118} \mathrm{~N}_{9} \mathrm{O}_{12}$ requires 1228.8900.

4.2.7. Boc-[L-Leu-L-Leu-(1S,3R)-Ac $\left.c_{6} C^{3 M}\right]_{3}-O M e$

$(5 b)$. Nonapeptide $\mathbf{5 b}$ was prepared from $\mathbf{4 b}$ and $\mathbf{3 b}$ in a manner similar to that described for the preparation of hexapeptide $\mathbf{4 b}$ :
R.; Santini, A.; Saviano, M.; Kamphuis, J. J. Pept. Sci. 1997, 3 , 110-122.

4. (a) Bardi, R.; Piazzesi, A. M.; Toniolo, C.; Sukumar, M.; Raj, P. A.; Balaram, P. Int. J. Pept. Protein Res. 1985, 25, 628-639; (b) Paul, P. K. C.; Sukumar, M.; Bardi, R.; Piazzesi, A. M.; Valle, G.; Toniolo, C.; Balaram, P. J. Am. Chem. Soc. 1986, 108, 63636370; (c) Pavone, V.; Benedetti, E.; Barone, V.; Di Blasio, B.; Lelj, F.; Pedone, C.; Santini, A.; Crisma, M.; Bonora, G. M.; Toniolo, C. Macromolecules 1988, 21, 2064-2071; (d) Crisma, M.; Bonora, G. M.; Toniolo, C.; Bavoso, A.; Benedetti, E.; Di Blasio, B.; Pavone, V.; Pedone, C. Macromolecules 1988, 21, 2071-2074; (e) Valle, G.; Crisma, M.; Toniolo, C.; Sen, N.; Sukumar, M.; Balaram, P. J. Chem. Soc. Perkin Trans. 2 1988, 393-398; (f) Benedetti, E.; Di Blasio, B.; Pavone, V.; Pedone, C.; Santini, A.; Crisma, M.; Toniolo, C. Acta Crystallogr. Sect. C 1989, 45, 634-638; (g) Fabiano, N.; Valle, G.; Crisma, M.; Toniolo, C.; Saviano, M.; Lombardi, A.; Isernia, C.; Pavone, V.; Di Blasio, B.; Pedone, C.; Benedetti, E. Int. J. Pept. Protein Res. 1993, 42, 459-465.

5. (a) Chacko, K. K.; Srinivasan, R.; Zand, R. J. Cryst. Mol. Struct. 1971, 1, 261-269; (b) Varughese, K. I.; Chacko, K. K.; Zand, R. Acta Crystallogr. Sect. B 1975, 31, 866-868; (c) Strässler, C.; Linden, A.; Heimgartner, H. Helv. Chim. Acta 1997, 80, 15281554.

6. Rodríguez-Ropero, F.; Zanuy, D.; Casanovas, J.; Nussinov, R.; Alemán C. J. Chem. Inf. Model. 2008, 48, 333-343.

7. Hirata, T.; Ueda, A.; Oba, M.; Doi, M.; Demizu, Y.; Kurihara, M.; Nagano, M.; Suemune, H.; Tanaka, M. Tetrahedron 2015, 71, $2409-2420$

8. (a) Toniolo, C.; Benedetti, E. Trends Biochem. Sci. 1991, 16, 350-353; (b) Liskamp, R. M. J. Recl. Trav. Chim. Pays-Bas. 1994, 113, 1-19; (c) Pal, L.; Basu, G.; Chakrabarti, P. Proteins: Struct. Funct. Genet. 2002, 48, 571-579; (d) Toniolo, C.; Crisma, M.; Formaggio, F.; Peggion, C.; Broxterman, Q. B.; Kaptein, B. Biopolymers (Pept. Sci.) 2004, 76, 162-176.

9. (a) Demizu, Y.; Tanaka, M.; Nagano, M.; Kurihara, M.; Doi, M.; Maruyama, T.; Suemune, H. Chem. Pharm. Bull., 2007, 55, 840842; (b) Demizu, Y.; Doi, M.; Kurihara, M.; Okuda, H.; Nagano, M.; Suemune, H.; Tanaka, M. Org. Biomol. Chem. 2011, 9, 3303-3312.

10. Oba, M.; Nonaka, H.; Doi, M.; Tanaka, M. Biopolymers (Pept. Sci.) 2016, 106, 210-218.

11. (a) Palumbo, M.; Da Rin, S.; Bonora, G. M.; Toniolo, C. Makromolekulare Chem. 1976, 177, 1477-1492; (b) Lorenzi, G. P.; Greco, G.; Mona, R. Biopolymers 1975, 14, 237-240.

12. (a) Wüthrich, K. NMR of Proteins and Nucleic Acids, New York, John Wiley \& Sons, 1986; (b) Wagner, G.; Neuhaus, D.; Wörgötter, E.; Vasak, M.; Kägi, J. H. R.; Wüthrich, K. J. Mol. Biol. 1986, 187, 131-135.

13. (a) Toniolo, C.; Polese, A.; Formaggio, F.; Crisma, M.; Kamphuis, J. J. Am. Chem. Soc. 1996, 118, 2744-2745; (b) Yoder, G.; Polese, A.; Silva, R. A. G. D.; Formaggio, F.; Crisma, M.; Broxterman, Q. B.; Kamphuis, J.; Toniolo, C.; Keiderling, T. A. J. Am. Chem. Soc. 1997, 119, 10278-10285; (c) Pengo, P.; Pasquato, L.; Moro, S.; Brigo, A.; Fogolari, F.; Broxterman, Q. B.; Kaptein, B.; Scrimin, P. Angew. Chem. Int. Ed. 2003, 42, 3388-3392.

14. (a) Sheldrick, G. M. Program System for Crystal Structure Refinement (SHELXL 97): University of Göttingen: Göttingen, 1997; (b) Beurskens, P. T.; Admiraal, G.; Beurskens, G.; Bosman, W. P.; de Gelder, R.; Israel, R.; Smits, J. M. M. The DIRDIF-99 program system, Technical Report of the Crystallography Laboratory, University of Nijmegen: The Netherlands, 1994.

15. CCDC-1469315 (4b), 1469316 (5a), and $1469317(\mathbf{5 b})$ contain the supplementary crystallographic data for this paper. These data can be obtained free of charge from The Cambridge Crystallographic Data Centre via: www.ccdc.cam.ac.uk/data_request/cif.

16. (a) Crisma, M.; Saviano, M.; Moretto, A.; Broxterman, Q. B.; Kaptein, K.; Toniolo, C. J. Am. Chem. Soc. 2007, 129, 1547115473; (b) Bellanda, M.; Mammi, S.; Geremia, S.; Demitri, N.; Randaccio, L.; Broxterman, Q. B.; Kaptein, B.; Pengo, P.; Pasquato, L.; Scrimin, P. Chem. Eur. J. 2007, 13, 407-416; (c) Moretto, A.; Formaggio, F.; Kaptein, B.; Broxterman, Q. B.; Wu, L.; Keiderling, T. A.; Toniolo, C. Biopolymers (Pept. Sci.) 2008, $90,567-574$.

17. (a) Horstmann, T. E.; Guerin, D. J.; Miller, S. J. Angew. Chem. Int. Ed., 2010, 39, 3635-3638; (b) Mbofana, C. T.; Miller, S. J. J. Am. Chem. Soc. 2014, 135, 3285-3292. 
18. (a) Akagawa, K.; Kudo, K. Adv. Synth. Catal. 2011, 353, 843847; (b) Akagawa, K.; Sen, J.; Kudo, K. Angew. Chem. Int. Ed., 2013, 52, 11585-11588.

19. (a) Nagano, M.; Doi, M.; Kurihara, M.; Suemune, H.; Tanaka, M. Org. Lett. 2010, 12, 3564-3566; (b) Demizu, Y.; Yamagata, N.; Nagoya, S.; Sato, Y.; Doi, M.; Tanaka, M.; Nagasawa, K.; Okuda, H.; Kurihara, M. Tetrahedron 2011, 67, 6155-6165. 


\section{Graphical Abstract}

To create your abstract, type over the instructions in the template box below.

Fonts or abstract dimensions should not be changed or altered.

\section{Helical structures of L-Leu-based peptides having} chiral six-membered ring amino acids

Leave this area blank for abstract info.

Tomohiro Umeno, Atsushi Ueda, Makoto Oba, Mitsunobu Doi, Takayuki Hirata, Hiroshi Suemune, and Masakazu Tanaka*
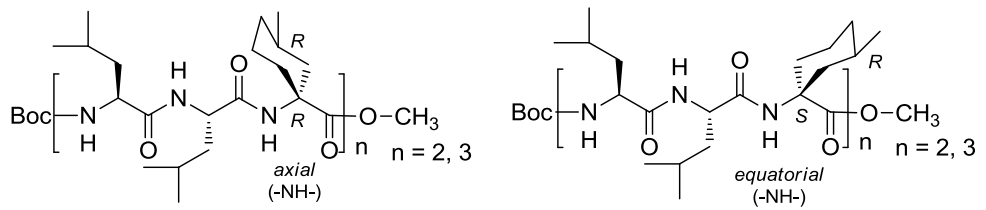

Boc- $\left\{\right.$ L-Leu-L-Leu-[(1R,3R)-Ac $\left.\left.\mathrm{c}_{6} \mathrm{c}^{3 \mathrm{M}}\right]\right\}_{\mathrm{n}}-\mathrm{OMe}$

Boc- $\left\{\right.$ L-Leu-L-Leu-[(1S,3R)-Ac $\left.\left.\mathrm{C}^{3 \mathrm{M}}\right]\right\}_{\mathrm{n}}-\mathrm{OMe}$ 